\title{
Coral Patch seamount (NE Atlantic) - a sedimentological and megafaunal reconnaissance based on video and hydroacoustic surveys
}

\author{
C. Wienberg ${ }^{1}$, P. Wintersteller ${ }^{1}$, L. Beuck ${ }^{2}$, and D. Hebbeln ${ }^{1}$ \\ ${ }^{1}$ Center for Marine Environmental Sciences, University of Bremen, Bremen, Germany \\ ${ }^{2}$ Senckenberg am Meer, Marine Research Department, Wilhelmshaven, Germany \\ Correspondence to: C. Wienberg (cwberg@marum.de)
}

Received: 7 December 2012 - Published in Biogeosciences Discuss.: 19 December 2012

Revised: 4 April 2013 - Accepted: 29 April 2013 - Published: 27 May 2013

\begin{abstract}
The present study provides new knowledge about the so far largely unexplored Coral Patch seamount which is located in the NE Atlantic Ocean half-way between the Iberian Peninsula and Madeira. For the first time a detailed hydroacoustic mapping (MBES) in conjunction with video surveys (ROV, camera sled) were performed to describe the sedimentological and biological characteristics of this subelliptical ENE-WSW elongated seamount. Video observations were restricted to the southwestern summit area of Coral Patch seamount (water depth: $560-760 \mathrm{~m}$ ) and revealed that this part of the summit is dominated by exposed hard substrate, whereas soft sediment is just a minor substrate component. Although exposed hardgrounds are dominant for this summit area and, thus, offer suitable habitat for settlement by benthic organisms, the benthic megafauna shows rather scarce occurrence. In particular, scleractinian framework-building cold-water corals are apparently rare with very few isolated and small-sized live occurrences of the species Lophelia pertusa and Madrepora oculata. In contrast, dead coral framework and coral rubble are more frequent pointing to a higher abundance of cold-water corals on Coral Patch during the recent past. This is even supported by the observation of fishing lines that got entangled with rather fresh-looking coral frameworks. Overall, long lines and various species of commercially important fish were frequently observed emphasising the potential of Coral Patch as an important target for fisheries that may have impacted the entire benthic community. Hydroacoustic seabed classification covered the entire summit of Coral Patch and its northern and southern flanks (water depth: 560-2660 m) and revealed ex-
\end{abstract}

tended areas dominated by mixed and soft sediments at the northern flank and to a minor degree at its easternmost summit and southern flank. Nevertheless, these data also predict most of the summit area to be dominated by exposed bedrock which would offer suitable habitat for benthic organisms. By comparing the locally restricted video observations and the broad-scale monitoring of a much larger and deeper seafloor area as derived by hydroacoustic seabed classification, it becomes obvious that habitat information obtained by in situ sampling may provide a rather scattered pattern about the entire seamount ecosystem. Solely with a combination of both methods, a satisfactory approach to describe the diverse characteristics of a seamount ecosystem can be derived which is in turn indispensable for future scientific monitoring campaigns as well as management and conservation purposes.

\section{Introduction}

Seamounts are defined as isolated topographic features of the seabed that have a limited lateral extent and rise more than $1000 \mathrm{~m}$ from abyssal depths (Menard, 1964). Large seamounts usually originate as volcanoes and are primarily associated with intraplate hotspots and mid-ocean ridges (Staudigel et al., 2010). It is estimated that there exist tens of thousands of seamounts in the world's ocean (Wessel et al., 2010), thereby being en masse one of the largest biomes on Earth (Etnoyer et al., 2010). Hence, although seamounts are globally significant habitats (Kitchingman and Lai, 2004; Yesson et al., 2011), to date fewer than 300 seamounts 
have been surveyed or even sampled and studied worldwide (Stocks, 2004; Etnoyer et al., 2010; Morato et al., 2013). In recent years seamounts have gained increasing interest (Mironov et al., 2006; Bergstad et al., 2008; Christiansen and Wolff, 2009) mainly because of their possible important role as local biodiversity hotspots (Richer de Forges et al., 2000; Samadi et al., 2006). For example, it has long been recognised that many seamounts harbour large aggregations of demersal or benthopelagic fish (Koslow, 1997; Morato and Pauly, 2004; Pitcher et al., 2007; Morato et al., 2009, 2010). The environmental conditions around a seamount, which acts as an abrupt and isolated topographic obstacle on the seafloor, are characterised by substantially enhanced currents (e.g., Rogers, 1994) and productivity (Genin et al., 1986; Genin, 2004). In addition, seamounts regularly contain hard substrate habitats in contrast to the background soft sediments that dominate the deep ocean (Rogers, 1994). All these aspects together may promote a rich benthic fauna that is typically dominated by suspension-feeding organisms, of which cold-water corals and sponges are dominant elements (Genin et al., 1986; Wilson and Kaufmann, 1987; Rogers, 1994; Probert et al., 1997; Koslow et al., 2001; Stocks, 2004; Gage et al., 2005; Clark et al., 2006). Nevertheless, biological studies on seamounts are still rare and address only single aspects of seamount systems, and it is under debate whether the defined tenets of seamounts, as summarised above, are rather over-generalisations of a broad range of environmental types encountered on seamounts (McClain, 2007; Clark et al., 2010; Rowden et al., 2010). Finally, though many of the worldwide existing seamount ecosystems still need to be explored, they are already threatened by economic exploitation such as bottom trawling and mining for mineral resources (Grigg et al., 1987; Koslow et al., 2000; Clark et al., 2007, 2010).

In the warm temperate region of the NE Atlantic, seamounts are located along the Mid-Atlantic ridge, near the Azores and close to the Canary and Madeira Islands. For the latter region, a $700 \mathrm{~km}$-long belt of irregularly spaced seamounts stretches from SW Iberia to the Madeira archipelago (Fig. 1). These seamounts belong to the southern margin of the Azores-Gibraltar Zone, a plate boundary between Eurasia and Africa (Buforn et al., 1988). The seamounts are late Mesozoic to Recent in age and reflect the north-eastward movement of the African plate over the Madeira volcanic hotspot with Madeira Island being the most recent volcanic construction (Geldmacher and Hoernle, 2000; Surugiu et al., 2008). The seamounts are surrounded by abyssal plains (Tagus, Horseshoe, Seine; Fig. 1) and ascend from water depths of 4000 to $4800 \mathrm{~m}$ up to a few hundred metres below the sea surface, except from Gorringe bank and Ampère seamount whose summits reach the photic zone in water depths of 25 to $60 \mathrm{~m}$. The so-called Horseshoe seamounts (comprising e.g., Gorringe bank, Ampère, Coral Patch, and Josephine seamounts) surrounding the Horseshoe abyssal plain consist of basalts and tuffs (Hatzky, 2005). Be- cause of their volcanic origin and their remoteness from any detritic sediment input, they commonly provide only two types of benthic habitats (a) hard substrata, and (b) bioclastic sand formed by the remnants of benthic organisms colonising the seamounts and pelagic organisms (von Rad, 1974).

The area of the Horseshoe seamounts is situated well inside the North Atlantic subtropical gyre and is directly influenced by the eastward flowing Azores Current (Stramma, 2001). At intermediate water depths $(700-2000 \mathrm{~m})$ the seamounts are influenced by the Mediterranean Outflow Water (MOW) and the Antarctic Intermediate Water (AAIW) (van Aken, 2000). The MOW is most prominent between 900 to $1500 \mathrm{~m}$ depth with higher temperatures and salinities, but lower oxygen content than adjacent Atlantic seawater (Halbach et al., 1992). It flows westward through the Strait of Gibraltar and enters the seamount area unimpaired from the eastern side before it flows through the passages between the seamounts. Below the MOW and AAIW flows the North Atlantic Deep Water (NADW) in a southward direction between $2000 \mathrm{~m}$ to $3000 \mathrm{~m}$ depth. This water mass is again underlain by the Antarctic Bottom Water (AABW) flowing northward (van Aken, 2000). The seamounts themselves act as a kind of disturbed crossing of the major oceanic flow systems described above that may cause partial mixing of the water masses. Thereby, ocean currents encountering a seamount cause upwelling on its upstream side. If these currents are steady and strong enough they will lead to the formation of a Taylor column, an anticyclonic eddy above the summit (Chapman and Haidvogel, 1992; White et al., 2005, 2007 and references therein).

The study presented here focuses on the Coral Patch seamount which comprises the eastern part of Ampère bank, with Ampère seamount being its western counterpart (Fig. 1). The Coral Patch seamount was discovered in 1883 during an expedition for laying telegraph cable between Cádiz and the Canary Islands (Buchanan, 1885). Buchanan (1885) remarks that a dredge from $\sim 970 \mathrm{~m}$ water depth revealed many fragments of the crinoid Neocomatella pulchella (Pourtalès, 1878 ) and a large quantity of live occurrences of the coldwater coral Lophelia pertusa, the latter findings presumably giving the inspiration for the geographic name. Coral Patch is a sub-elliptical ENE-WSW elongated seamount, about $120 \mathrm{~km}$ long and $70 \mathrm{~km}$ wide (D'Oriano et al., 2010). Bathymetric and seismic data show that Coral Patch is a composite structure as it originates from a pre-existing sedimentary structural high that extends to a water depth of up to $2500 \mathrm{~m}$ (Zitellini et al., 2009) while on the upper part of the seamount volcanic edifices are emplaced (D'Oriano et al., 2010). Eight distinct coalescent volcanic cones were identified to cluster on the southwestern top of Coral Patch seamount, while in the northeast a single isolated cone of $8 \mathrm{~km}$ in diameter is developed (called Vince volcano; D'Oriano et al., 2010). According to D'Oriano et al. (2010) the southwestern top reaches at its shallowest part a water depth of about $\sim 645 \mathrm{~m}$, therefore, it belongs to the group of "deep" seamounts which 


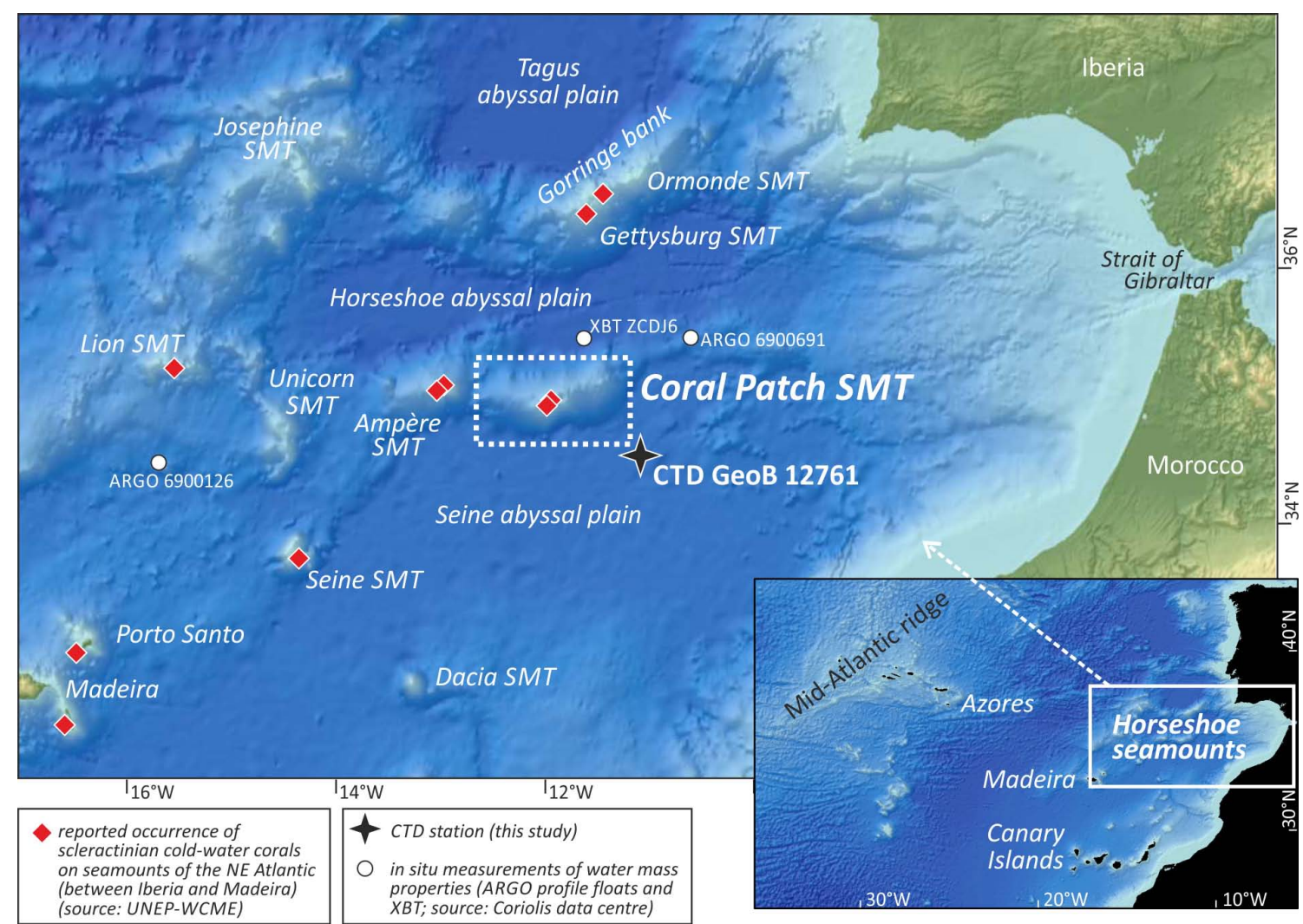

Fig. 1. Overview map (source: GEBCO) showing seamounts (SMT) of the NE Atlantic Ocean (between Iberia and Madeira) including the Coral Patch seamount (dashed box). Reported occurrences of scleractinian cold-water corals found on these seamounts are indicated (red diamonds; data are extracted from UNEP World Conservation Monitor Centre (UNEP-WCMC) global cold-water coral dataset v.2.0, 2006). Position of CTD station GeoB 12761 conducted during R/V PELAGIA cruise 64PE284 is marked by the black star. Positions of two ARGO floats and one XBT station providing additional data of water mass properties in the surrounding area of Coral Patch seamount (source: www.coriolis.eu.org; see Sect. 2.3) are indicated by white dots.

are defined to arise with their summits to a water depth of up to $400 \mathrm{~m}$ (Martin and Christiansen, 2009). However, so far the knowledge about this seamount is still rather scattered, in particular, regarding its biotic cover (Buchanan, 1885; D'Oriano et al., 2010).

The present study aims to accomplish, for the first time, a detailed sedimentological and biological reconnaissance of Coral Patch seamount. By combining video observations, faunal sampling and hydroacoustic data, the primary objective of this reconnaissance is to define the facies or habitat types occurring on top of Coral Patch seamount. This information is associated with the distribution, abundance and diversity of the benthic biota, whereby special emphasis is placed on the occurrence of scleractinian cold-water corals. Finally, evidence for anthropogenic activities will help to determine potential environmental impacts of fishing activities on the megafaunal benthic community.

With the approach to analyse hydroacoustic data for its backscatter information, interpreted in conjunction with the video-derived in situ ground-truthing data, a mapping tool is applied that generates extrapolated seabed classification maps in short times, at low costs, and over large areas of the seafloor (e.g., Kostylev et al., 2001; Roberts et al., 2005; Blondel and Gómez Sichi, 2009; Brown and Blondel, 2009; Coiras et al., 2011). Thereby predictive maps of benthic habitats are derived which are essential for sustained monitoring, management and conservation purposes of marine ecosystems (Pickrill and Tood, 2003; Davies et al., 2008; Schlacher et al., 2010).

Although this case study concentrates on one individual seamount and applies a rather descriptive approach, it will help to identify factors controlling the abundance of benthic populations on Coral Patch in particular and, thus, will add valuable information on the large variability of Atlantic seamounts in general providing the opportunity to put this individual seamount into a comparative context to adjacent seamounts. 
Table 1. Metadata of HOPPER camera sled and ROV CHEROKEE video surveys conducted at Coral Patch seamount during R/V PELAGIA cruise 64PE284. Metadata of ROV samples collected during R/V PELAGIA cruise 64PE284 and grab samples collected during R/V VICTOR HENSEN cruise VH97. Abbreviations: WD water depth, TL track length, RD recording duration. See Figs. 2 and 3 for position and orientation of dive tracks and sampling positions.

\begin{tabular}{|c|c|c|c|c|c|c|c|c|}
\hline Station-ID & Gear & & Date & UTC [hh:mm] & Latitude [N] & Longitude [W] & $\mathrm{WD}[\mathrm{m}]$ & $\mathrm{TL} / \mathrm{RD}$ \\
\hline \multicolumn{9}{|l|}{ Video surveys } \\
\hline \multirow{2}{*}{ GeoB12763 } & camera & Start: & 6 Mar 2008 & $11: 13$ & $34^{\circ} 56.40^{\prime}$ & $11^{\circ} 58.03^{\prime}$ & 685 & $1.28 \mathrm{~km}$ \\
\hline & sled & End: & 6 Mar 2008 & $12: 07$ & $34^{\circ} 56.47^{\prime}$ & $11^{\circ} 58.66^{\prime}$ & 738 & $0: 54 \mathrm{~h}$ \\
\hline \multirow{2}{*}{ GeoB12764 } & camera & Start: & 6 Mar 2008 & $13: 52$ & $34^{\circ} 56.40^{\prime}$ & $11^{\circ} 56.96^{\prime}$ & 745 & $1.35 \mathrm{~km}$ \\
\hline & sled & End: & 6 Mar 2008 & $14: 42$ & $34^{\circ} 56.28^{\prime}$ & $11^{\circ} 57.65^{\prime}$ & 710 & $0: 50 \mathrm{~h}$ \\
\hline \multirow{2}{*}{ GeoB12767 } & \multirow{2}{*}{ ROV } & Start: & 7 Mar 2008 & $10: 24$ & $34^{\circ} 56.45^{\prime}$ & $11^{\circ} 57.71^{\prime}$ & 718 & $1.57 \mathrm{~km}$ \\
\hline & & End: & 7 Mar 2008 & $13: 28$ & $34^{\circ} 56.71^{\prime}$ & $11^{\circ} 58.45^{\prime}$ & 760 & $3: 04 \mathrm{~h}$ \\
\hline \multicolumn{9}{|c|}{ Seabed samples } \\
\hline GeoB12767a & ROV & & 7 Mar 2008 & $10: 56$ & $34^{\circ} 56.51^{\prime}$ & $11^{\circ} 57.80^{\prime}$ & 698 & I \\
\hline GeoB12767b & ROV & & 7 Mar 2008 & $11: 42$ & $34^{\circ} 56.55^{\prime}$ & $11^{\circ} 57.93^{\prime}$ & 668 & l \\
\hline GeoB12767c & ROV & & 7 Mar 2008 & $12: 16$ & $34^{\circ} 56.57^{\prime}$ & $11^{\circ} 58.03^{\prime}$ & 666 & l \\
\hline VH97-91 & grab & & spring 1997 & / & $34^{\circ} 58.00^{\prime}$ & $11^{\circ} 57.30^{\prime}$ & 1050 & I \\
\hline VH97-92 & grab & & spring 1997 & l & $34^{\circ} 57.00^{\prime}$ & $11^{\circ} 55.90^{\prime}$ & 890 & l \\
\hline
\end{tabular}

\section{Material and methods}

All data used to describe the sedimentological, biological and hydrographical characteristics of Coral Patch seamount derived from video surveys, hydroacoustic mapping, and one CTD measurement that were conducted during R/V PELAGIA expedition 64PE284 in spring 2008 (Hebbeln and cruise participants, 2008; Fig. 1). In addition, seabed samples were analysed for its megafaunal content to complement information about faunal diversity on Coral Patch seamount (Fig. 2). Three samples were collected during a video survey with a remotely operated vehicle (ROV) in water depths between 670 and $700 \mathrm{~m}$ (Table 1, Figs. 2, 3). During a former cruise in 1997 with R/V VICTOR HENSEN (VH97), two Van Veen grab samples were collected north and northwest of the video surveys in water depths of 890 and $1050 \mathrm{~m}$, respectively (Table 1, Fig. 2; A. Freiwald, personal communication, 2012). All samples were qualitatively analysed for its faunal content.

\subsection{Video surveys}

Three video surveys were carried out by means of a camera sled and an ROV to obtain in situ data about the facies distribution and the megafauna on Coral Patch seamount. Two surveys (GeoB 12763 and GeoB 12764; Table 1) were carried with a camera sled (designed by the Royal NIOZ, Texel, The Netherlands) providing real-time video observations. This so-called HOPPER camera sled is equipped with a downward-looking camera and a purpose-built digital videorecording system. Videos, time- and position-referenced data were simultaneously stored to produce GIS (Geographic In- formation System) based plots of the sled track and associated data.

In addition, one dive (GeoB 12767; Table 1) was carried out with the ROV CHEROKEE (Sub-Atlantic, Aberdeen, Scotland; operated by MARUM, Bremen, Germany). The ship-based IXSEA global positioning system (GAPS) coupled with the ship's differential global acoustic positioning system (DGPS) provided an absolute positioning accuracy within $0.2 \%$ of the slant range. The ROV is equipped with four video cameras including a colour video zoom camera for detailed seafloor observation and a digital still camera. The cameras are further equipped with three lasers for object size measurements on the seafloor. Laser scaling was adjusted to $19.5 \mathrm{~cm}$ in horizontal and $12 \mathrm{~cm}$ in vertical direction. All video and still image data were digitally stored. Navigational data (ship, ROV), video recordings, and still images are all time referenced. During ROV video observation three faunal samples were collected, thereby two samples were directly collected with its hydraulically operated manipulator and one sample was collected with a net connected to the ROV's manipulator. The sampling net had a mesh size of $1 \mathrm{~mm}$ allowing the sampling of fine material.

The track lengths of the three video surveys carried out on Coral Patch seamount varied between 1.28 and $1.57 \mathrm{~km}$ (length calculated on the distance between dive start and dive end; Table 1) and had an ENE-WSW to ESE-WNW orientation (Figs. 2, 3). A total of approximately four hours of video footage was recorded (Table 1). In addition, more than 100 high-resolution photographs were taken with the ROV's still camera and three seafloor samples were collected. The video surveys focussed on the southwestern top area of the seamount and covered a water depth range between 


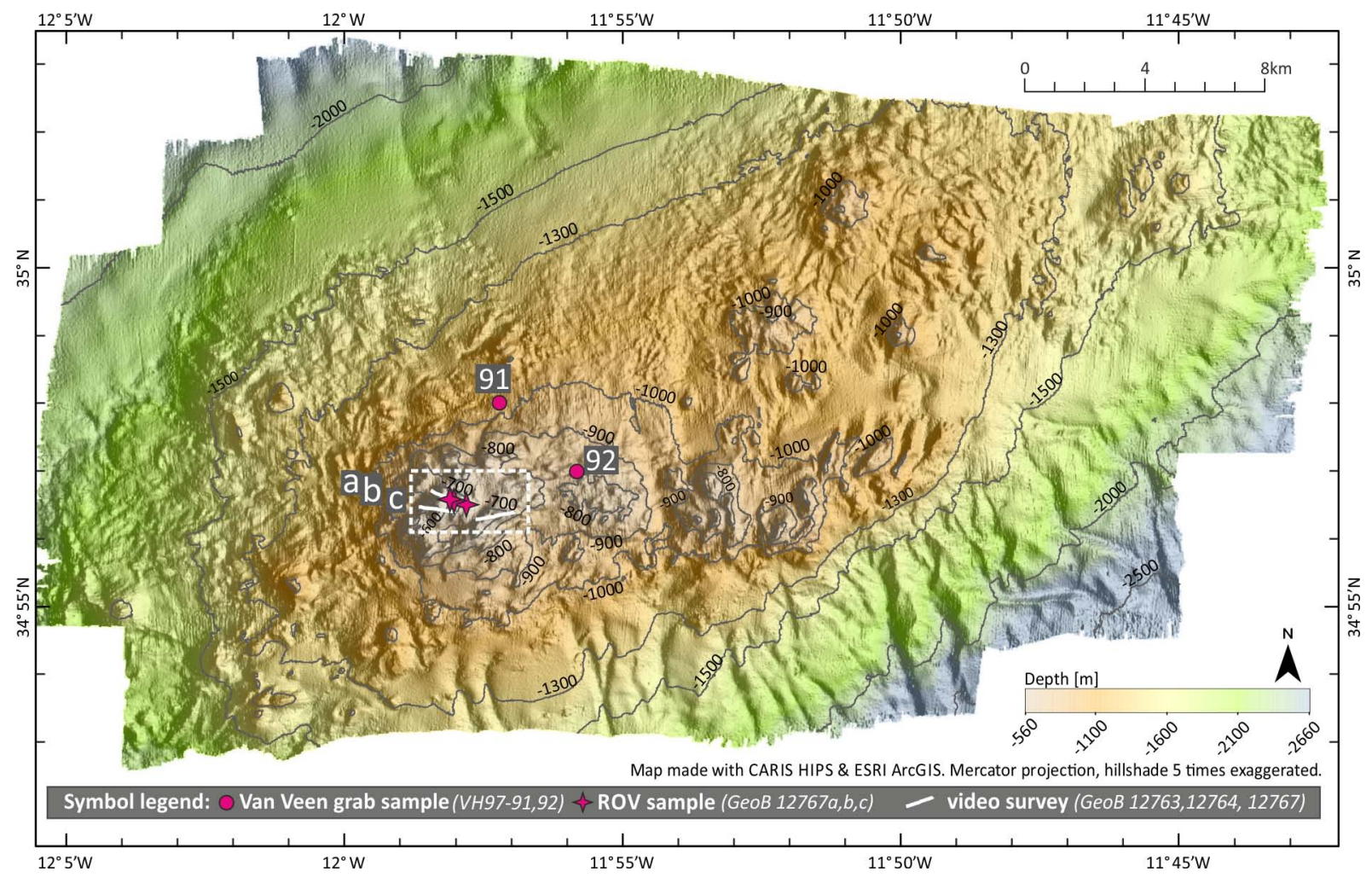

Fig. 2. Bathymetric map of Coral Patch seamount covering an area of $560 \mathrm{~km}^{2}$ and a water depth range between 560 and $2660 \mathrm{~m}$ (Mercator projection, 5 times exaggerated, shaded relief). Displayed are the ENE-WSW elongated summit and the northern and southern flanks of the seamount, the latter being incised by several canyon-like structures. Inserted box shows video-surveyed area (white lines indicate survey tracks) at the south-western top (see Fig. 3). Pink stars indicate ROV samples (a, b, c) and pink dots indicate position of Van Veen grab samples $(91,92)$ collected during R/V VICTOR HENSEN cruise VH97 (Table 1).

560 and $760 \mathrm{~m}$, thereby crossing the shallowest peak of the seamount's summit (GeoB 12763; Figs. 2, 3).

\subsection{Video analyses and classification scheme}

The complete video footage plus high-resolution images photographed with the ROV's still camera, were qualitatively analysed to describe the variety of geological and biological characteristics as well as human-mediated disturbances present on Coral Patch seamount. According to the Coastal and Marine Ecological Classification Standard of the Federal Geographic Data Committee (FGDC-CMECS, 2012), the classification scheme used in this study is built up of different groups of components comprising substrate components (SC; for examples see Fig. 4), biotic components (BC; for examples see Fig. 5), and anthropogenic impact components (AIC). All components are described separately and are subsequently divided into sub-classes (Fig. 3). Thereby, the defined SCs describe the character and composition of the surface substrate (Table 2) and are treated as a primary (basic) layer (Fig. 3), while BCs and AICs overlay the SCs as secondary layers (Fig. 3). The defined BCs solely comprise the occurrence of scleractinian cold-water corals that varies from isolated live coral colonies to coral rubble, and the occurrence of fishes, isolated or as schools (Figs. 3, 4). The remaining benthic fauna (comprising sessile and mobile organisms) was not considered for classification due to its low occurrence. All identified organisms (scleractinian coldwater corals, other benthic megafauna, and fishes) were listed in Table 3. And finally, AICs describe litter and remnants of fisheries (Fig. 3).

The applied configuration offers the opportunity to produce a comprehensive compilation of all characteristics of the seamount and to easily access all potential combinations of natural and anthropogenic features (FGDC-CMECS, 2012). Moreover, this kind of classification is more applicable for comparison with existing, as well as upcoming, classification studies of seamounts. A similar approach has already successfully been applied for various seabed structures in the NE Atlantic Ocean hosting deep-sea ecosystems (e.g., coldwater coral mounds, mud volcanoes, cliffs; Wienberg et al., 2008, 2009). 


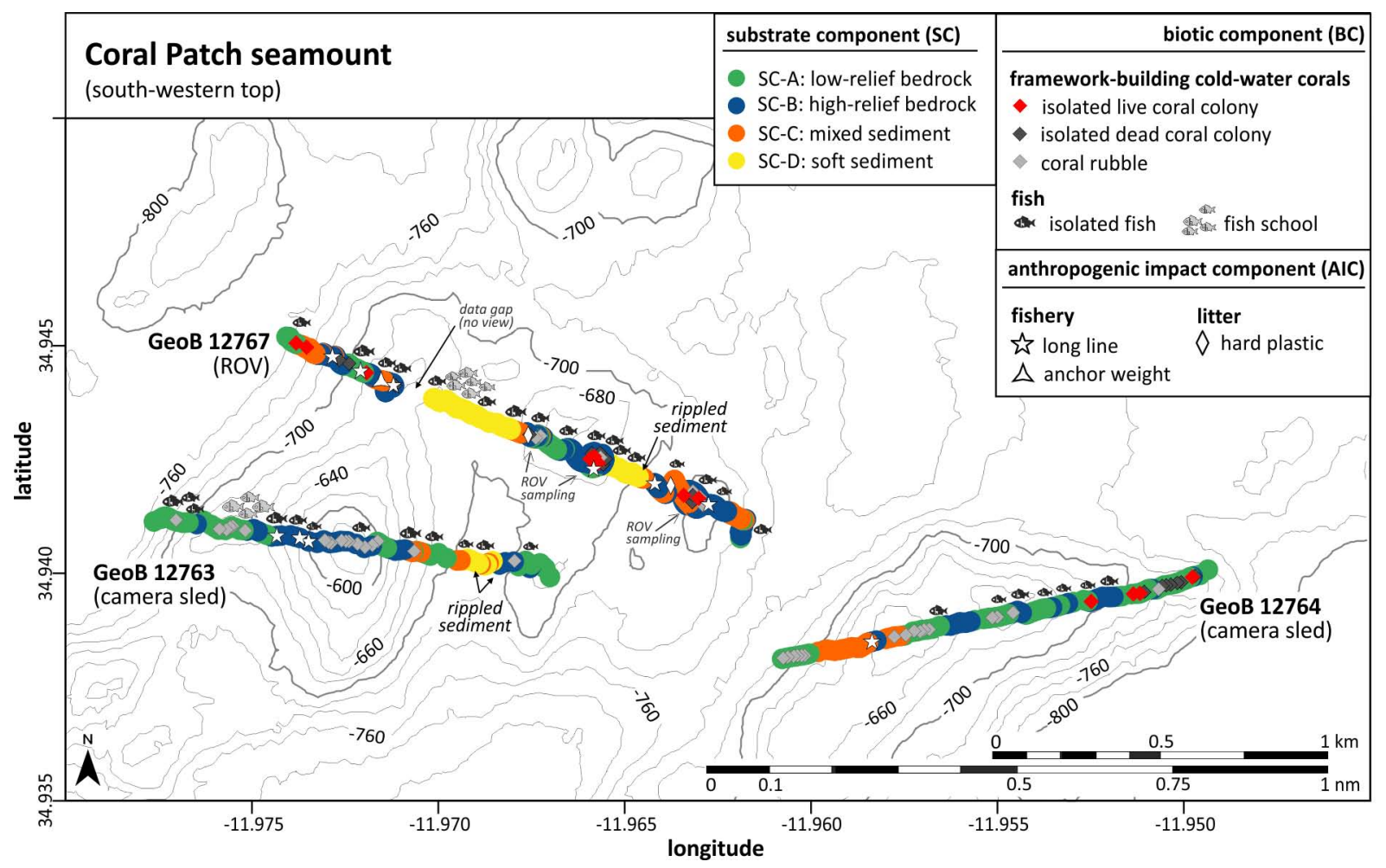

Fig. 3. Isobath-map of the southwestern top area of Coral Patch seamount. Contour interval is $20 \mathrm{~m}$. The map is overlain by video survey tracks (camera sled: GeoB 12763, 12764; ROV: GeoB 12767) that were analysed for substrate components (SC; for more details see Table 2), biotic components (BC; framework-building cold-water corals and fishes), and anthropogenic impact components (AIC; litter, fishery).

\subsection{Hydroacoustic imaging and topographic zonal classification}

Seabed mapping on Coral Patch seamount was performed using a KONGSBERG EM300 multibeam echosounder system (MBES) which operates at a frequency of $30 \mathrm{kHz}$ and uses 135 equidistant beams per ping. An angular coverage of $120^{\circ}$ was maintained during the surveys. The footprint of a single beam is limited to $1^{\circ}$ by $2^{\circ}$. The motion of the vessel was registered by a KONGSBERG MRU-5 motion reference unit, and the ship's position and heading were determined with two GPS antennas. Motion and position information was combined in a SEAPATH 200 Real Time Kinematic (RTK) sensor to provide fast and highly accurate real-time heading, attitude and position information with a dynamic accuracy of $0.02^{\circ}$ for roll and pitch. The EM300 was calibrated with a proper sound velocity profile calculated from salinity, pressure and temperature data recorded by a SEABIRD CTD system (verified by additional data derived from two ARGO profile floats and one XBT measurement recorded in the surrounding area of Coral Patch seamount, see Fig. 1 for position; source: www.coriolis.eu.org). The CTD was applied in close vicinity to the Coral Patch seamount (station GeoB 12761; Fig. 1) and lowered to a maximum water depth of $2500 \mathrm{~m}$.
Bathymetric data processing was carried out with the CARIS HIPS \& SIPS (v.7.1) data processing software. An area of $560 \mathrm{~km}^{2}$ was mapped, manually edited and resulted in a bathymetric grid of $20 \mathrm{~m}$ cell size, covering water depths between 560 and $2660 \mathrm{~m}$ (Fig. 2). The grid resolution was chosen according to the data density and MBES footprint. Total propagated uncertainties (TPU) were used to validate the final grid-product. In order to generate TPU values for each sounding, the uncertainty estimates for each of the contributing sensor measurements had to be combined using a propagation algorithm. The results are separated in uncertainty estimates for the depth (DpTPU), and the horizontal position of the sounding (HzTPU), and scaled to the $95 \%$ confidence-interval which is equivalent to $1.96 \times$ the standard deviation.

The bathymetric grid was initial point for further topographic analysis conducted with the Benthic Terrain Modeler (BTM) tool (Wright et al., 2005). The BTM was utilised to calculate (a) standardised (to avoid spatial auto-correlation) Bathymetric Position Indexes (BPI), which indicate the position of a referenced location relative to its surrounding, (b) rugosity, which is a measure of terrain complexity (texture or "bumpiness" of the seabed), and (c) the slope (for detailed information see Lundblad et al., 2006). According to a classification scheme based on Greene et al. (1999) 

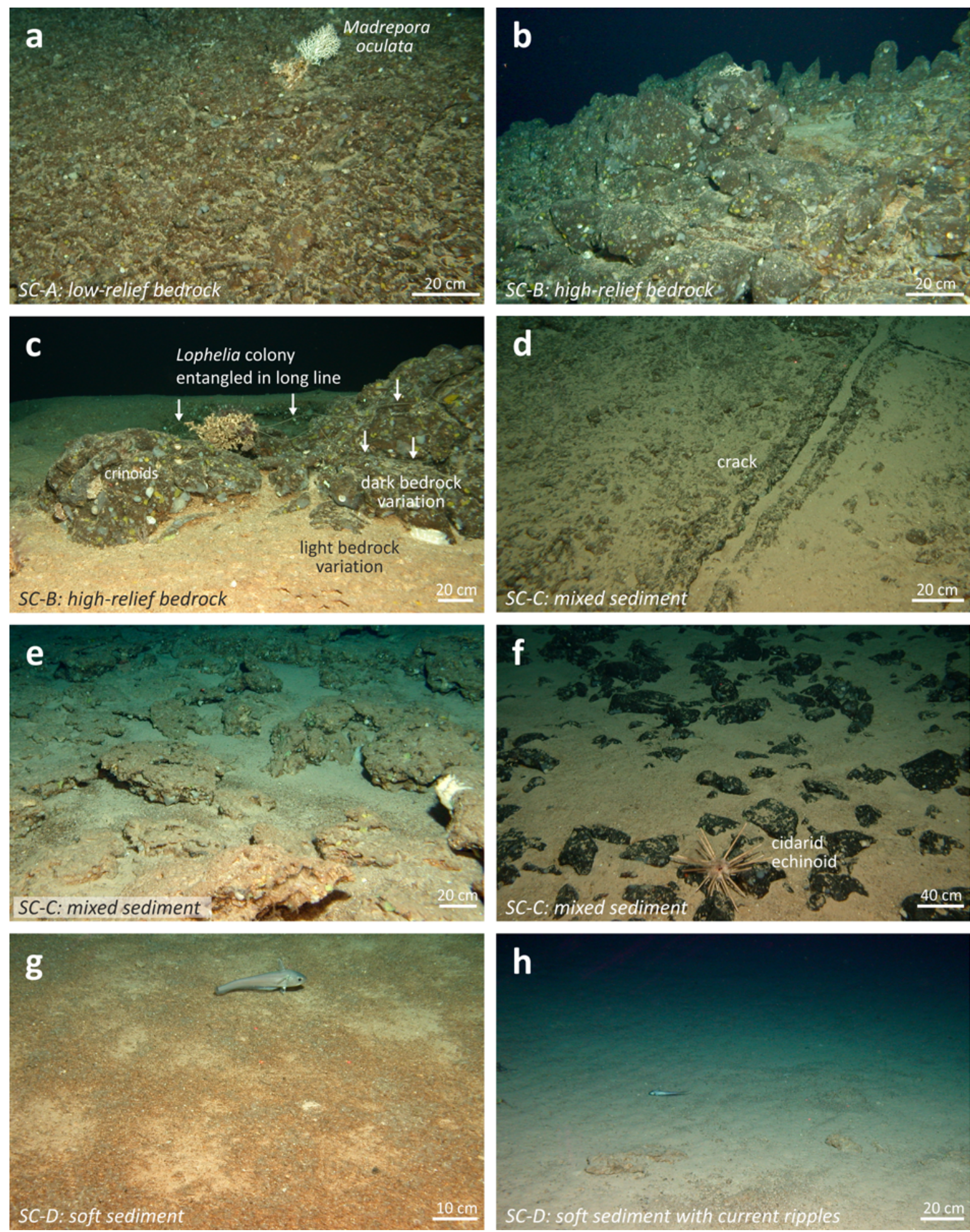

Fig. 4. ROV still images showing the variety of substrate components (SC) present on Coral Patch seamount (see also Table 2). (a) low-relief (smooth) basaltic bedrock (SC-A); (b) high-relief bedrock with small pockets filled with soft sediment (SC-B); (c) high-relief bedrock (SC-B) showing the two colour variations of bedrock; note Lophelia colony entangled in long line; (d) mixed sediment (SC-C): bedrock covered by a thin veneer of soft sediment; note the larger crack in the middle and the smaller one in the right upper corner; (e) mixed sediment (SC-C): pancake-like crusts with depressions in between filled with soft sediment (SC-C) (f) mixed sediment (SC-C): scattered basaltic pebble- to cobble-sized rock on soft sediment (SC-D); (g) soft sediment (SC-D); (h) soft sediment with current ripples (SC-D). 
Table 2. Substrate component classes (SC) defined to describe the landscape of the southwestern top area of Coral Patch seamount. SCs were defined based on the visual analyses of video footage and high-resolution images (colour code according to Fig. 3). See ROV images presented in Fig. 4 for examples of SCs.

\begin{tabular}{|c|c|c|c|}
\hline SC ID & SC Name & Colour code & Characteristics \\
\hline SC-A & $\begin{array}{l}\text { low-relief bedrock } \\
\text { (Fig. 4a) }\end{array}$ & green & $\begin{array}{l}\text { extensive areas with bedrock outcrops } \\
\text { (including slabs, crusts, banks); surface has a } \\
\text { smooth appearance and exhibits signs of } \\
\text { weathering, bio-erosion and strong encrustation } \\
\text { by various organisms }\end{array}$ \\
\hline SC-B & $\begin{array}{l}\text { high-relief bedrock } \\
\text { (Fig. } 4 \mathrm{~b}, \mathrm{c} \text { ) }\end{array}$ & blue & $\begin{array}{l}\text { rugged surface due to abundant crevices and } \\
\text { cracks, scarp sequences; small-sized pockets } \\
\text { filled with soft sediment; metre-sized boulders } \\
\text { and fields with centimetre- to decimetre-sized } \\
\text { pebbles and cobbles lying exposed on smooth } \\
\text { bedrock }\end{array}$ \\
\hline $\mathrm{SC}-\mathrm{C}$ & $\begin{array}{l}\text { mixed sediment } \\
\text { (Fig. } 4 d-\text { f) }\end{array}$ & red & $\begin{array}{l}\text { mixed facies composed of hard substrate and } \\
\text { soft sediment; thin sediment veneer }(<1 \mathrm{~cm}) \\
\text { irregularly covering bedrock; pancake-like } \\
\text { crusts with depressions between segments filled } \\
\text { with soft sediment; scattered gravel- to cobble- } \\
\text { sized rocks lying exposed on soft sediments }\end{array}$ \\
\hline SC-D & $\begin{array}{l}\text { soft sediments } \\
\text { (Fig. } 4 \mathrm{~g}, \mathrm{~h})\end{array}$ & yellow & $\begin{array}{l}\text { extensive plains of bioclastic sands (shells of } \\
\text { pelagic and benthic organisms); locally } \\
\text { restricted small-scaled current ripples (few } \\
\text { centimetres in height); very sporadically } \\
\text { scattered gravel- to pebble-sized rocks }\end{array}$ \\
\hline
\end{tabular}

and modified by Erdey-Heydorn (2008), topographic zonal classes were defined comprising, e.g., flat plains, slopes, depressions and ridges (for details see Table 4). With respect to the FGDC-CMECS (as applied for the video-based classification), these topographical classes are equivalents to geoform components (GC) which describe major geomorphic and structural characteristics of the seafloor (FGDCCMECS, 2012).

Zonal classification maps were produced based on two differently scaled BPI-pairs using the BTM's Zone Classification Builder (Fig. 6). The first map is based on broad-scale BPI of 80 units for the inner radius (IR) and 90 units for the outer radius (OR), and a fine-scale BPI of 10-IR to 15OR units. The second map utilises a broad-scale BPI of 10IR to 20-OR units, and a fine-scale BPI of 3-IR to 6-OR units (Fig. 6). One unit is equal to a cell size of $20 \mathrm{~m}$. The IR/OR-values were adjusted by trial-and-error considering the MBES footprint, swath width, and data density.

\subsection{MBES backscatter analyses and seabed classification}

Besides the water depth computed by the travel time of a transmitted and reflected wave signal, the hydroacoustic data obtained by an MBES provide also information about a number of seabed characteristics (e.g., Blondel, 2002; White et al., 2007). The shape of a returning wave signal (backscatter) reflects the sediment composition of the seabed, the seabed ruggedness, and biological components covering the seabed (Blondel and Murton, 1997; Lurton, 2002; van Rein et al., 2011). Thus, the backscatter information of an MBES can be used to classify and map seabed characteristics (e.g., Hamilton, 2011). Compared to locally restricted in situ information of seabed characteristics as obtained by video observation (limited to survey transects) or seabed samples (limited to sampling points), the remote hydroacoustic seabed classification offers the outstanding opportunity to image large areas of the seafloor and, thus, to generate predictive habitat maps which can be applied to optimise future scientific campaigns (Guisan and Zimmermann, 2000; Brown and Blondel, 2009; Guinan et al., 2009).

The post-processing of the MBES backscatter (beam-time series, in the following called "side-scan") obtained for the Coral Patch seamount was conducted with QPS Fledermaus Geocoder Tool (FMGT v.7.3.3pre). Since backscatter data are influenced by various parameters like slope and beam angle or artefacts from the water column, in a first step several corrections (e.g., initial radiometric correction), filters (adaptive angle varying gain, anti-aliasing), a beam pattern correction and a bathymetric reference grid were applied to maximise the information content within the backscatter signals. 

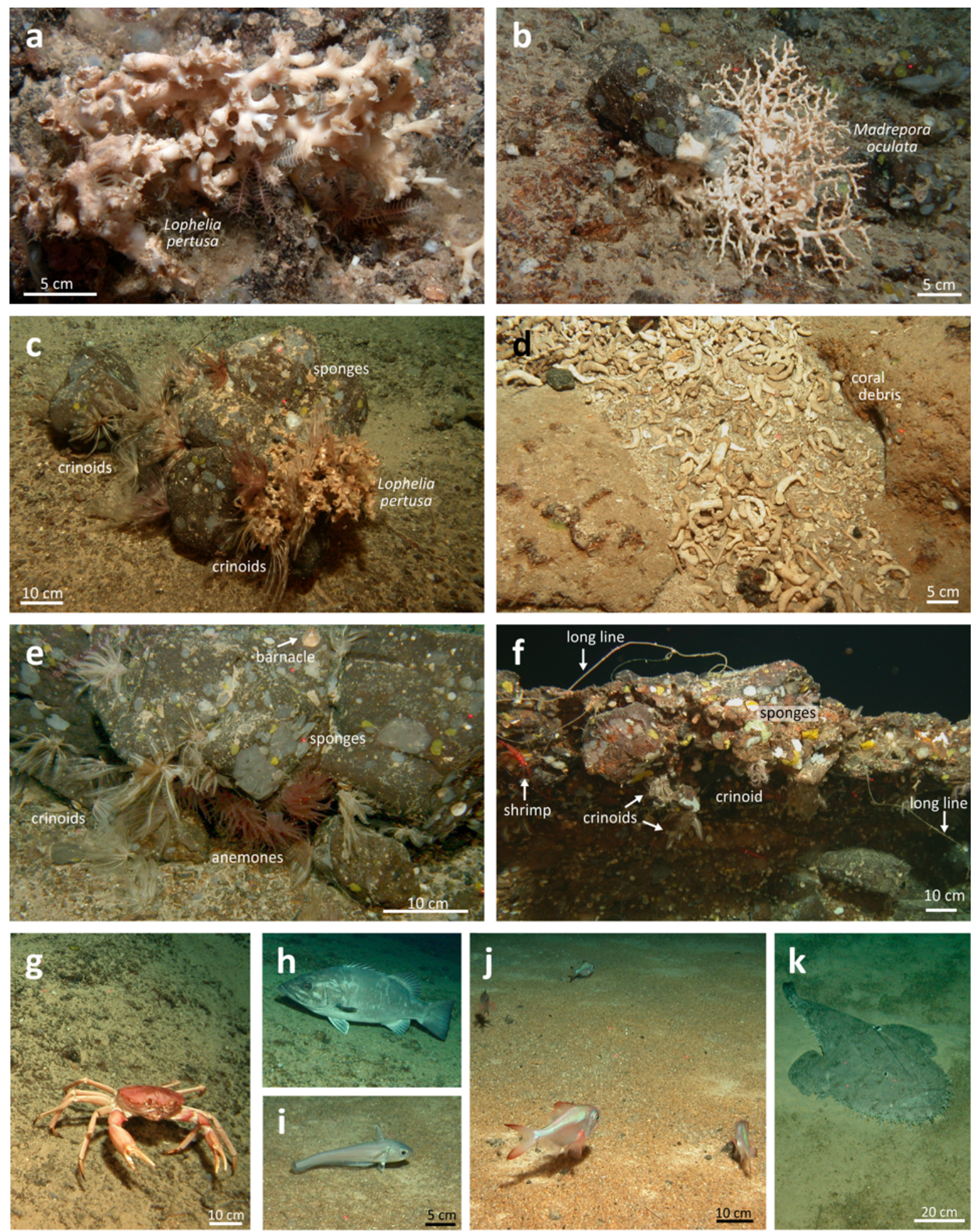

Fig. 5. ROV still images showing the variety of megafauna (BC: biotic components) present on Coral Patch seamount and one example for anthropogenic impact (AIC). (a) Lophelia pertusa colonised by hydrozoans and crinoids; (b) Madrepora oculata; (c) L. pertusa, crinoids and sponges colonising a cobble-sized rock; (d) coral rubble accumulation made up of dendrophylliid and solitary coral species; (e) crinoids, anemones and sponges on bedrock; (f) fishing line entangled with a rocky slab; (g) Geryon cf. longipes on bedrock, (h) Polyprion americanus; (i) Coelorinchus sp.; (j) Hoplostethus mediterraneus; (k) Lophius budegassa. 


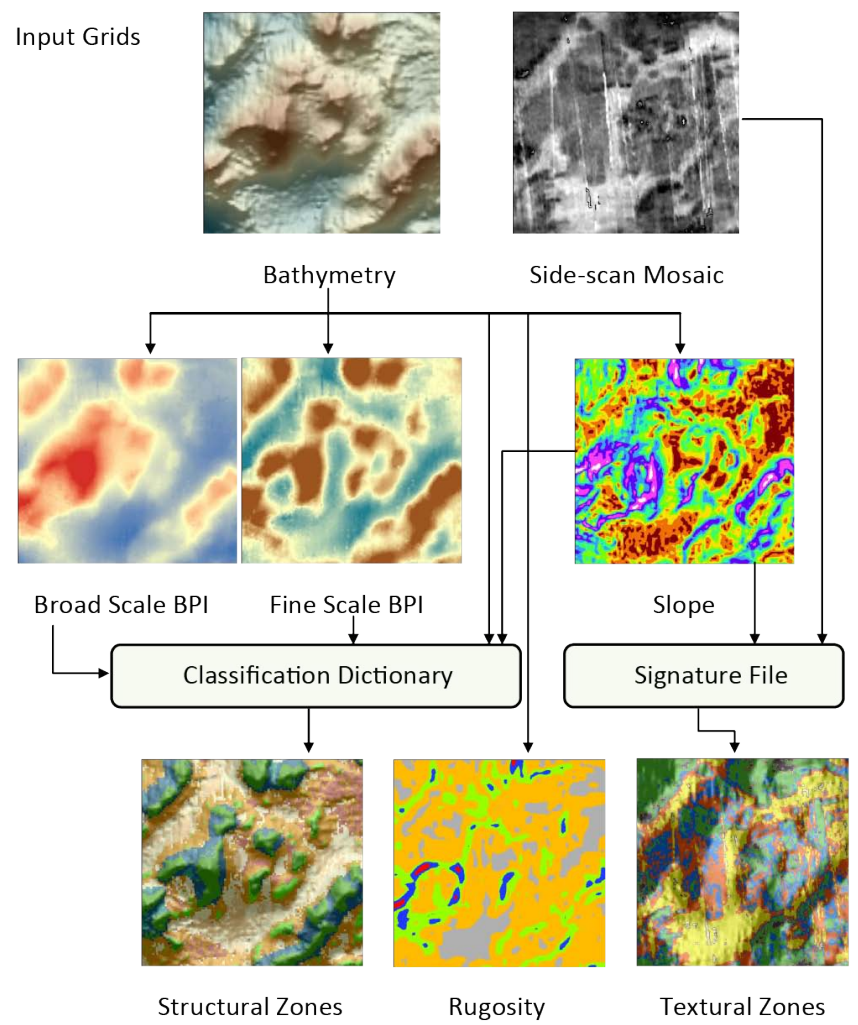

Fig. 6. Flowchart of hydroacoustic seabed classification methods applied for Coral Patch seamount. The dataset used for the flowchart displays a small area at the southwestern summit. The final products (last image row) represent (a) topographical characteristics based on the bathymetry and derived products (BPI: Bathymetric Position Index), and (b) textural classes based on the "side-scan" mosaic and hillshade/slope.

Where possible, no nadir information was used. The final product was a "side-scan" mosaic with a grid cell size of $15 \mathrm{~m}$ (Fig. 6). This mosaic was used to distinguish distinct substrate types (soft sediment, hard substrate) by supervised classification (Figs. 7, 8). The classification was verified by in situ ground-truthing data obtained during video observations (and seabed sampling) as described above. Thereby, the video analyses in combination with the FMGT patch analyser were used to outline training and test sites (see Fig. 7a (3) Textural seabed classification map and (4) "Side-scan" mosaic grid), which encompass the principal textures identified from the backscatter data. The FMGT patch analyser allows to compute or manually select the appropriate values for the current patch to run an "angle vs. range analysis" (ARA; for further details see Fonseca et al., 2009; Fonseca and Mayer, 2007). This method of seafloor characterisation is build-up of the comparison of the actual backscatter angular response with expected acoustic response curves based on a well-established mathematical model, the Jackson model (Jackson et al., 1986), which has been verified by thorough backscatter analyses of acoustic data derived from various echo sounders (e.g., Kongsberg EM300, EM1002, EM3002; for further details see Mulhearn, 2000). As the Jackson model does not consider seabed classes such as bedrocks and boulders, which are an important component of the seabed on Coral Patch seamount as revealed by the video analyses, the model could not directly be applied. Nevertheless, the FMGT patch analyser was used to gain knowledge of similar textural signatures outside the ground-truthed areas (see Fig. 7a-3/4). For textural classification a set of training samples were created to describe groupings of cells that belong to homogenous areas corresponding to certain seabed types identified in the ground-truthed areas. Based on these training samples the ArcGIS ${ }^{\mathrm{TM}}$ Image Classification Create Signature Tool was used to create an ASCII signature file of classes, which stores the multivariate statistics for each class or cluster of interest. The file includes the mean, the number of cells, and the variance-covariance matrix for each class or cluster. Finally, the ArcGIS ${ }^{\mathrm{TM}}$ Maximum Likelihood Classification Tool was used to assign each cell of the raster bands' common extent to one of the classes represented in the signature file (see also Guisan and Zimmermann, 2000). Overall, the procedure described above is closely related to the classification method introduced by Erdey-Heydorn (2008). However, the zonal and textural classifications were not combined in order to avoid an over-interpretation of the acoustic data.

\subsection{CTD Measurement}

To gain some information on the physical parameters of the water masses in the area of the Coral Patch seamount, one CTD measurement was accomplished in close vicinity to the seamount (station GeoB 12761: $34^{\circ} 31.21^{\prime} \mathrm{N}, 11^{\circ} 08.51^{\prime} \mathrm{W}$, $4430 \mathrm{~m}$ water depth; position is indicated in Fig. 1). The CTD measurement of the water column down to a maximum water depth of $2500 \mathrm{~m}$ was conducted using a SEABIRD "SBE 9 plus" underwater unit and a SEABIRD "SBE 11 plus" deck unit. The vertical profile over the water column provided standard data for conductivity, temperature and pressure. Additionally, the CTD was equipped with sensors for optical backscatter (turbidity), fluorescence (chlorophyll) and dissolved oxygen. Conductivity and temperature data were used to compute salinity (Fig. 9). A Temperature-Salinity $(T-S)$ plot was used to determine the water mass structure and stratification in the study area (Fig. 9). It needs to be mentioned here that the information on physical water mass properties derived from only one single CTD cast is limited and needs to be considered with caution as no temporal or spatial variability can be resolved. 
Table 3. List of faunal species identified on Coral Patch seamount based on video analyses presented in this study. The list is supplemented by the faunal content of three samples collected during ROV video observation (position indicated in Fig. 3), two Van Veen grab samples (position indicated in Fig. 2; unpublished data provided by A. Freiwald), and notes found in literature.

\begin{tabular}{|c|c|c|}
\hline Group & Species & Source \\
\hline PORIFERA & $?$ & this study \\
\hline \multicolumn{3}{|l|}{ CNIDARIA } \\
\hline $\begin{array}{l}\text { actinians } \\
\text { octocorals } \\
\text { scleractinians }\end{array}$ & $\begin{array}{l}\text { Errina } \text { sp. } \\
\text { Lepidopora } \text { sp. } \\
\text { Sertularella } \text { sp. } \\
\text { Stenohelia } \text { sp. } \\
\text { ?Stylaster sp. } \\
? \\
? \\
\text { Aulocyathus atlanticus } \\
\text { Balanophyllia cellulose } \\
\text { ?Caryophyllia sarsiae } \\
\text { Deltocyathus eccentricus } \\
\text { Deltocyathus moseleyi } \\
\text { Flabellum macandrewi? } \\
\text { Fungiacyathus crispus } \\
\text { Fungiacyathus fragilis } \\
\text { Peponocyathus folliculus } \\
\text { Stenocyathus vermiformis } \\
\text { ?Thrypticotrochus } \text { sp. } \\
\text { unident. solitary coral } \\
\text { Lophelia pertusa } \\
\text { Madrepora oculata } \\
\text { Dendrophyllia cornigera } \\
\text { Eguchipsammia cornucopia } \\
\text { ? }\end{array}$ & $\begin{array}{l}\text { VH97-91, } 92 \\
\text { VH97-91, } 92 \\
\text { D'Oriano et al. (2010) } \\
\text { VH97-91 } \\
\text { VH97-91, } 92 \\
\text { this study } \\
\text { this study } \\
\text { VH97-91, } 92 \\
\text { this study } \\
\text { VH97-91 } \\
\text { VH97-91 } \\
\text { VH97-91, } 92 \\
\text { VH97-91 } \\
\text { VH97-91 } \\
\text { VH97-91 } \\
\text { VH97-91 } \\
\text { VH97-91, 92 } \\
\text { VH97-91 } \\
\text { this study } \\
\text { this study; VH97-91; Buchanan (1885) } \\
\text { this study; VH97-91,92; D'Oriano et al. (2010) } \\
\text { this study } \\
\text { this study } \\
\text { this study }\end{array}$ \\
\hline \multicolumn{3}{|l|}{ ANNELIDA } \\
\hline serpulids & ?Filogranula stellata & VH97-91 \\
\hline \multicolumn{3}{|c|}{ ARTHROPODA } \\
\hline $\begin{array}{l}\text { crustaceans } \\
\text { brachiopods } \\
\text { barnacles }\end{array}$ & $\begin{array}{l}\text { Geryon cf. longipes } \\
\text { Pandalidae (cf. Aristeus) } \\
\text { (cf. Grypheus) } \\
\text { Terebratula sp. } \\
?\end{array}$ & $\begin{array}{l}\text { this study } \\
\text { this study } \\
\text { this study } \\
\text { D'Oriano et al. (2010) } \\
\text { this study }\end{array}$ \\
\hline \multicolumn{3}{|l|}{ MOLLUSCA } \\
\hline $\begin{array}{l}\text { bivalves } \\
\text { gastropods }\end{array}$ & $\begin{array}{l}\text { Asperarca } \mathrm{sp} . \\
\text { Amphissa acutecostata } \\
\text { Pedicularia } \mathrm{sp} .\end{array}$ & $\begin{array}{l}\text { D'Oriano et al. (2010) } \\
\text { D'Oriano et al. (2010) } \\
\text { VH97-91 }\end{array}$ \\
\hline \multicolumn{3}{|c|}{ ECHINODERMATA } \\
\hline $\begin{array}{l}\text { asteroids } \\
\text { crinoids } \\
\text { echinoids }\end{array}$ & $\begin{array}{l}? \\
\text { Neocomatella pulchella } \\
\text { Cidaris sp. }\end{array}$ & $\begin{array}{l}\text { this study } \\
\text { Buchanan (1885) } \\
\text { this study }\end{array}$ \\
\hline \multicolumn{3}{|l|}{ FISH } \\
\hline & $\begin{array}{l}\text { Lophius budegassa } \\
\text { Hoplostethus mediterraneus } \\
\text { Polyprion americanus } \\
\text { Coelorinchus sp. } \\
\text { Nezumia } \text { sp. }\end{array}$ & $\begin{array}{l}\text { this study } \\
\text { this study } \\
\text { this study } \\
\text { this study } \\
\text { this study }\end{array}$ \\
\hline
\end{tabular}



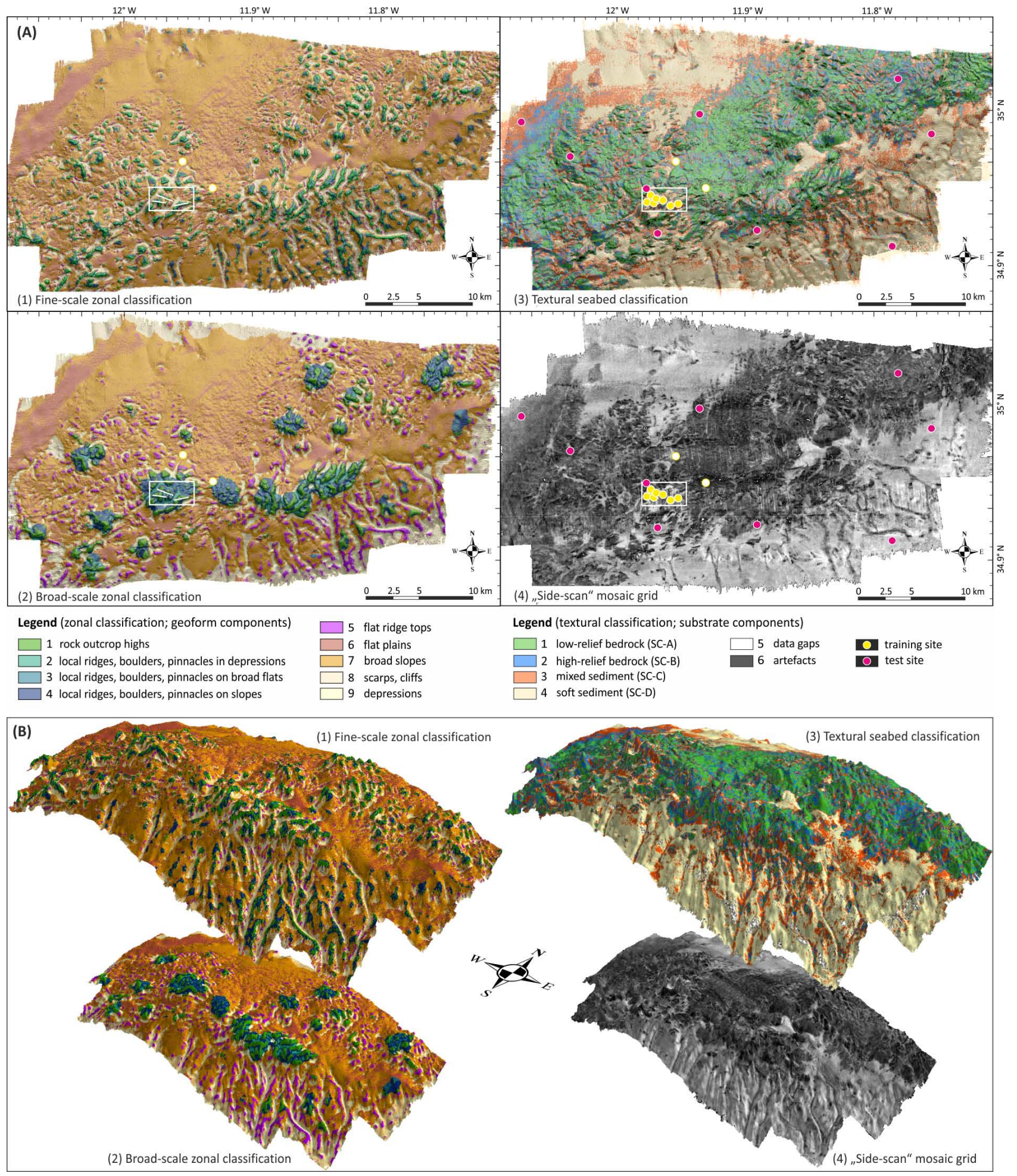

Fig. 7. Hydroacoustic seabed classification maps (A: 2D-plots, B: 3D-plots) of Coral Patch seamount. (1) Fine-scale and (2) broad-scale zonal classification maps both showing the distribution of geoform components (GC) comprising e.g., flat plains, slopes, boulders and local ridges (see Table 4 for detailed description). (3) Textural classification map showing the distribution of substrate components (SC; see Table 2 for detailed description). (4) "Side-scan" mosaic grid. Inserted boxes on (A) indicate video-surveyed area at the southwestern top of Coral Patch seamount, white dots show position of Van Veen grab sampling, both used as ground-truthing data for textural seabed classification. The location of the training and test sites are denoted in (A) (3) and (4). 


\section{Results}

\subsection{Video footage-based mapping}

\subsubsection{Substrate components (SC)}

Two major seafloor types dominate the landscape of the southwestern top area of the Coral Patch seamount: hard substrate and soft sediment, which are a function of the volcanic origin of the seamount (see Zitellini et al., 2009; D'Oriano et al., 2010) and of the accumulation of hemipelagic sediment (see also Auster et al., 2005). Variations and combinations of both main sediment types were defined into four SC classes (Table 2) representative for the specific sedimentological and geological features present on Coral Patch seamount.

Substrate component classes SC-A ("low-relief bedrock") and SC-B ("high-relief bedrock") describe both extensive areas with bedrock outcrops. Two colour variations were observed with dark brownish and light greyish to brownish bedrock, which might be related to the grade of alteration (Fig. 4c). Overall, the bedrock is strongly influenced by weathering, bio-erosion and encrustation of various organisms (e.g., sponges, bivalves) (Figs. $4 \mathrm{a}, \mathrm{b}$ and $5 \mathrm{e}, \mathrm{f}$ ). The main difference between both bedrock classes is related to seabed roughness. SC-A comprises large and plain slabs, crusts and banks that exhibit a smooth surface with occasional small-sized crevices (Fig. 4a). In contrast, SC-B has a rugged appearance which is attributed to the high abundance of crevices, cracks and caves (Fig. 4b). Metre-sized boulders and fields with centimetre- to decimetre-sized pebbles and cobbles, likely constituting strongly altered basaltic lava fragments (volcanic breccia), were found to lie exposed on smooth bedrock (Fig. 4c). At some places, successive scarps are present with each step having an elevation of up to $1 \mathrm{~m}$ (Figs. 4b, c). Whereas SC-A and SC-B are almost free of soft sediment except from occasional and small-sized sedimentfilled pockets, SC-C ("mixed sediment") comprises a mixture of hard substrate and soft sediment. Variations of this class comprise thin veneers of sediment $(<1 \mathrm{~cm}$ thickness) irregularly covering bedrock (Fig. 4d), altered crusts having a pancake-like appearance with depressions in between being filled with trapped sediment (Fig. 4e), and scattered gravel- to cobble-sized rocks lying exposed on soft sediment (Fig. 4f). SC-D ("soft sediment") describes extensive plains of soft sediment most likely comprising bioclastic sands formed by the shells of pelagic and benthic organisms (Fig. 4g). Current ripples occur locally restricted in small-sized fields and are just a few centimetres in height, whereas the wavelength is difficult to determine, but might be in the centi- to decimetre range as well (Fig. 4h). Just very sporadically scattered gravel- to pebble-sized rocks were observed.

Overall, exposed bedrock dominates the landscape of the video-surveyed area on the southwestern top of Coral Patch seamount and is mainly associated with morphological highs and steep slopes (Fig. 3). In contrast, areas with mixed and soft sediments just account for approximately one third of the surveyed area, thereby being related to morphological depressions. The largest soft sediment plain with a lateral extension of $\sim 350 \mathrm{~m}$ corresponds to a morphological depression that was crossed during survey GeoB 12767 (Fig. 3).

\subsubsection{Biogenic and anthropogenic impact components (BC and AIC)}

The megafauna on Coral Patch seamount comprises benthic to epibenthic living organisms, which were observed as live occurrences as well as their skeletal remnants (e.g., shell hash, coral rubble), and demersal fish fauna (note that solely cold-water corals and fishes are defined as biogenic components in Fig. 3). Overall, the number of megafaunal organisms is rather low (Figs. 4, 5; Table 3). Higher occurrences were only found for cidarid echinoids (Fig. 4f) and crinoids with the latter mostly being attached to current-exposed boulders and below sediment-sheltered overhangs of e.g., ledges (Fig. 5c, e). Minor components of the benthic community are stylasterids, anemones, octocorals, antipatharians, asteroids and crustaceans (mainly decapod crabs, i.e. Geryon cf. longipes; Fig. 5g). Moreover, exposed rocky boulders and bedrock outcrops (SC-A, SC-B) are often strongly colonised by various species of small-sized sponges, and to a lesser degree incrusted by brachiopods (cf. Grypheus), bivalves and barnacles (Fig. 5c, e, f). Special emphasis was placed on the occurrence of scleractinian cold-water corals (defined as biotic components in Fig. 3). Live colonies of the species Lophelia pertusa and Madrepora oculata are rare and just comprise isolated small-sized $(<0 \mathrm{~cm}$ in diameter) frameworks with apical live portions including up to 2 polyp generations (defined as the successive sequence of asexuallyproduced polyps along a colony branch; Fig. 5a, b). Live coral colonies are solely associated to hard substrate, thereby being mainly found to colonise on high-relief bedrock (SCB). Isolated dead coral colonies and coral rubble are more frequent as just $15 \%$ of all scleractinian coral observations were identified to comprise live colonies. Thereby, it is obvious that larger accumulations of coral rubble correspond to the highest elevations observed during the video surveys (Fig. 3). In particular, the prominent peak crossed during video survey GeoB 12763 that arises to a water depth of up to $560 \mathrm{~m}$ is characterised by the highest density of coral rubble (Fig. 3).

The identification of organisms solely based on video footage is sometimes problematic (in particular, to a genus or species level), and needs to be verified by seabed samples. A total of three samples were collected during ROV dive GeoB 12767 (Table 1, Figs. 2, 3). Two samples comprised fossil remnants of $L$. pertusa (and very few small live Lophelia polyps). One net sample collected with the ROV contained various scleractinian cold-water corals which were identified as L. pertusa, M. oculata, Eguchipsammia cornucopia, Dendrophyllia cornigera, and several solitary 

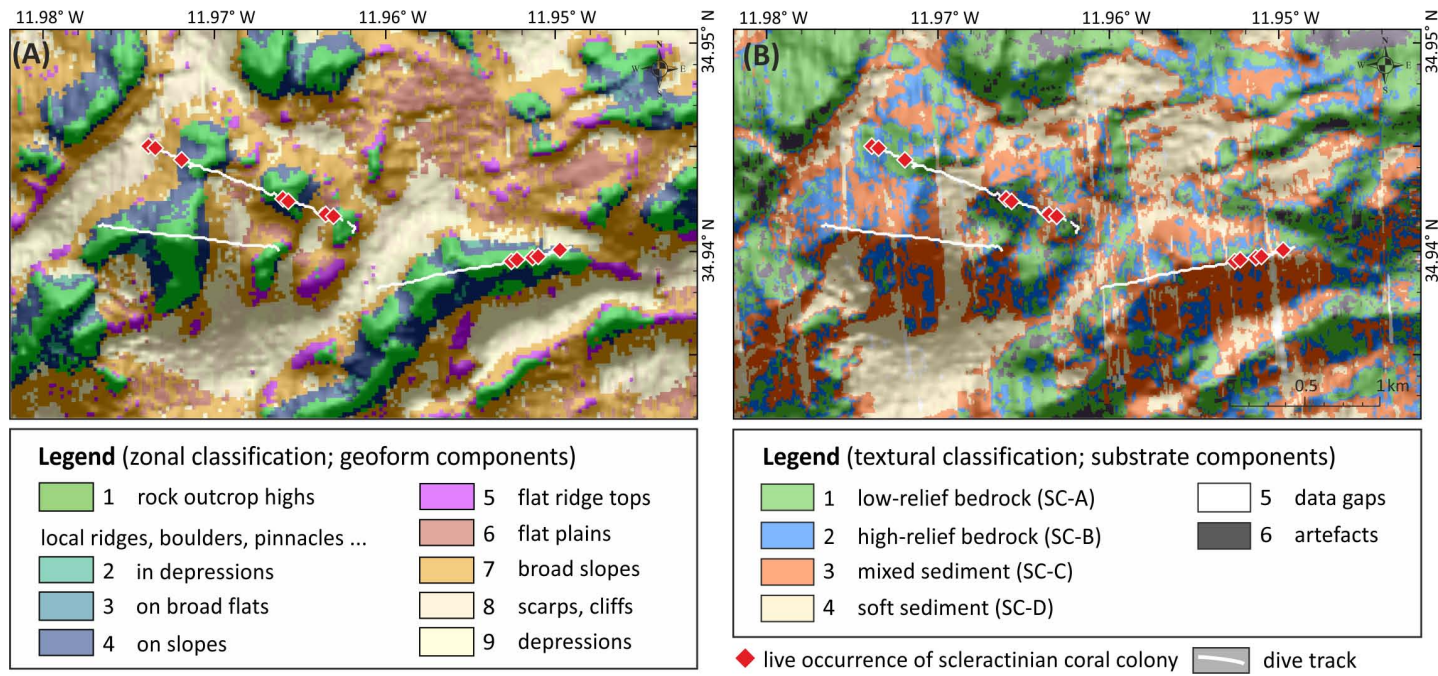

Fig. 8. Hydroacoustic seabed classification maps displaying the video-surveyed area on the southwestern summit of Coral Patch seamount. (A) Fine-scale zonal classification (geoform components; see Table 4 for detailed description), and (B) textural seabed classification (substrate components; see Table 2 for detailed description). White lines: video transects; red diamonds: occurrence of live framework-building scleractinian cold-water corals observed during video observation (see also Fig. 3).

Table 4. Decision table summarising the topographical features (column a) used for the zonal classification (modified after Erdey-Heydorn, 2008). The Bathymetric Position Index (BPI) numbers (columns b, c) are given in grid units. Therefore, the BPI data were standardised by subtracting the mean value of the BPI data from each BPI data point and dividing by the standard deviation; in this way the BPI data point had a value of 0 and the standard deviation had a value of $-1 /+1$. The standardised value of each data point was then multiplied by 100 . The slope values (column d) are given in degrees $\left(5^{\circ}\right.$ and $\left.45^{\circ}\right)$ as a cut-off level for different declination ranges (see also Erdey-Heydorn, 2008 ; Micalleff et al., 2012).

\begin{tabular}{|c|c|c|c|c|c|c|c|}
\hline & a & \multicolumn{2}{|c|}{$\mathrm{b}$} & \multicolumn{2}{|c|}{$\mathrm{c}$} & \multicolumn{2}{|c|}{ d } \\
\hline \multicolumn{2}{|r|}{ Classification } & \multicolumn{2}{|c|}{ Broad Scale BPI } & \multicolumn{2}{|c|}{ Fine scale BPI } & \multicolumn{2}{|c|}{ Slope } \\
\hline Class & Seabed Structure & lower & upper & lower & upper & lower & upper \\
\hline 1 & rock outcrop highs, narrow ridges & 100 & & 100 & & & \\
\hline 2 & local ridges, boulders, or pinnacles in depressions & & -100 & 100 & & & \\
\hline 3 & local ridges, boulders, or pinnacles on broad flats & -100 & 100 & 100 & & & 5 \\
\hline 4 & local ridges, boulders, or pinnacles on slopes & -100 & 100 & 100 & & 5 & \\
\hline 5 & flat ridge tops & 100 & & -100 & 100 & & \\
\hline 6 & flat plains & -100 & 100 & -100 & 100 & & 5 \\
\hline 7 & broad slopes & -100 & 100 & -100 & 100 & 5 & 45 \\
\hline 8 & scarps, cliffs & -100 & 100 & -100 & -100 & 5 & \\
\hline 9 & depressions (incl. scours, gullies) & & -100 & & -100 & & \\
\hline
\end{tabular}

corals (Table 3). The fine fraction ( $>1 \mathrm{~mm}$ ) of the net sample was composed of benthic and planktonic foraminifers, pteropods, bryozoans, serpulids, small gastropods, and shell hash. Additional information on the megafauna was obtained by analysing two grab samples, which were sampled during a previous cruise with the R/V VICTOR HENSEN (VH9791 and 92; Table 1, Fig. 2). Also within these samples several fossil scleractinian cold-water corals (mainly solitary species) and various stylasterids were identified (Table 3).

During video observation, dead but relatively freshlooking coral thickets were often observed to be entangled in lost fishing lines (in particular during ROV dive GeoB 12767; Figs. 4c, 5f) indicating that the seamount is likely highly frequented by fishing activities. This assumption is even strengthened by the observation of a species-rich fish population comprising Lophius budegassa, Hoplostethus mediterraneus, Polyprion americanus as well as macrourid fish, like Coelorinchus and Nezumia (Fig. 5, Table 3). Overall, clear evidence for anthropogenic impact were found at several places at the top of Coral Patch seamount which mainly comprised the remnants of fishing lines (i.e., long lines) that got entangled with rocky boulders or coral colonies and an 
(A)

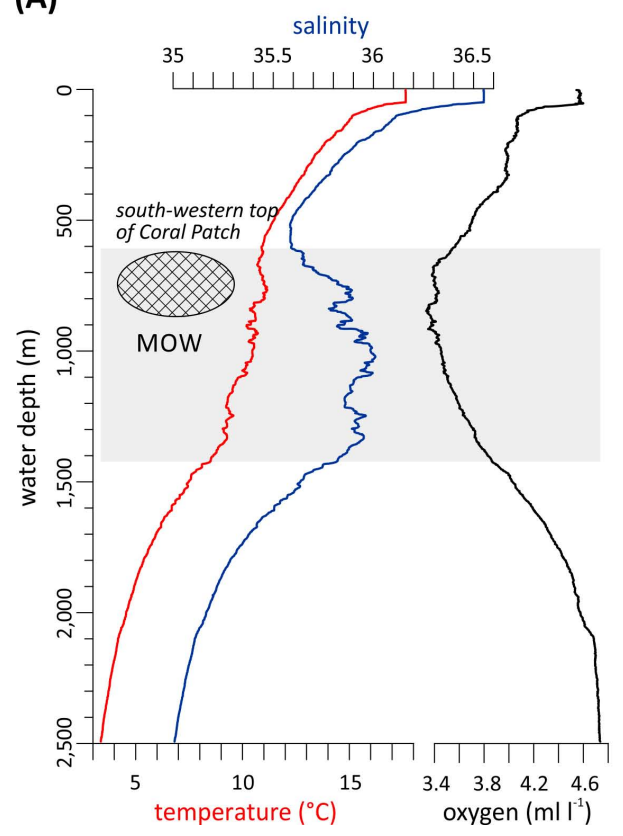

(B)

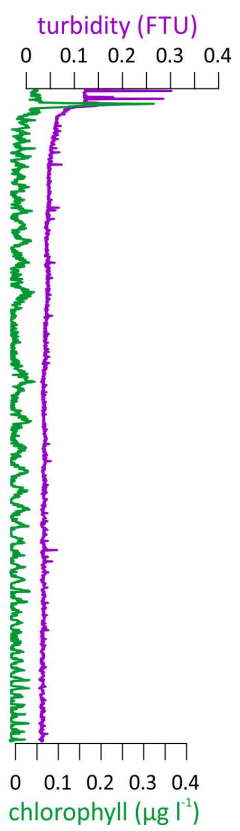

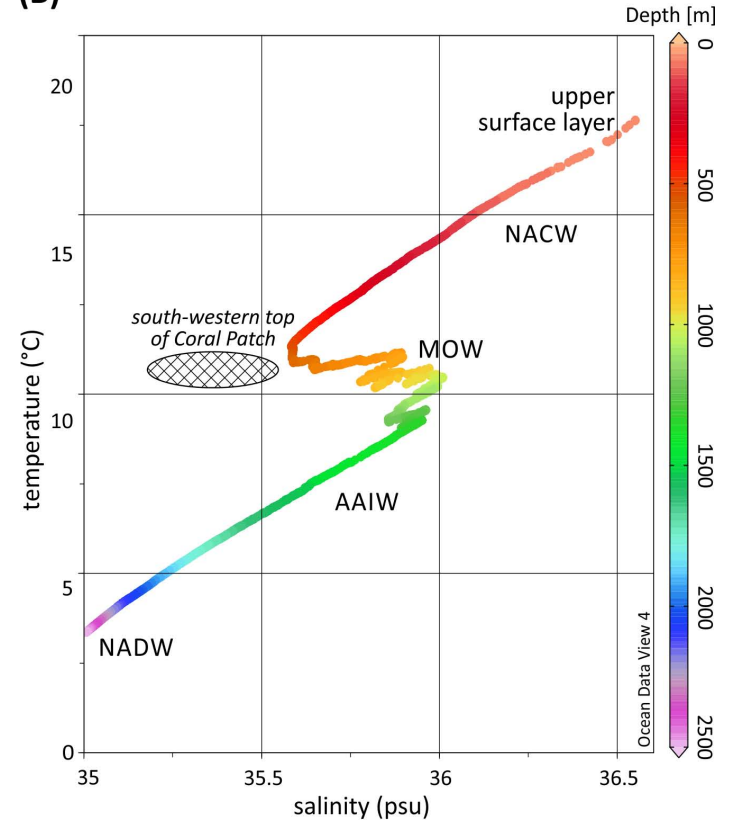

Fig. 9. (A) CTD profile (temperature, salinity, oxygen, fluorescence, turbidity), and (B) temperature and salinity $(T-S)$ plot obtained for CTD station GeoB 12761. The CTD was lowered to a maximum depth of 2,500 m southeast of Coral Patch seamount (see Fig. 1 for position). Major water masses are indicated: NACW North Atlantic Central Water, MOW Mediterranean Outflow Water, AAIW Antarctic Intermediate Water, NADW North Atlantic Deep Water (plotted using Ocean Data View v.4.5.1; http://odv.awi.de; Schlitzer, R., 2012). According to our bathymetric data the southwestern top covers on average a water depth range between 600 and $900 \mathrm{~m}$ (indicated by the ruled ellipse), hence, is directly influenced by the upper part of the MOW. (Note: only one single peak even has an elevation of up to $560 \mathrm{~m}$; see Figs. 2 and 3 ).

anchor weight (probably a stone). Only at two locations, litter comprising small-sized unidentified objects made up of hard plastic were discovered (Fig. 3).

\subsection{Hydroacoustic mapping}

In contrast to the video-based mapping, which is locally restricted to a rather small area at the southwestern summit of Coral Patch seamount comprising a water depth range of 560 to $760 \mathrm{~m}$ (Fig. 3), the hydroacoustic mapping encompasses an area of around $560 \mathrm{~km}^{2}$ and covers the entire summit and the northern and southern flanks of Coral Patch down to a water depth of $2660 \mathrm{~m}$ (Fig. 2). Thereby, information about topographical and sedimentological characteristics of the seamount could be expanded (extrapolated) to a much larger area of the seafloor resulting in a predictive map of potentially important benthic habitats on Coral Patch seamount, such as exposed hard substrate for cold-water corals (Figs. 7, 8).

\subsubsection{Bathymetric analysis, topographic zonal seabed classification}

Although the hydroacoustic mapping does not cover the entire expansion of Coral Patch seamount, its sub-elliptical shape with an ENE-WSW elongation and distinct coalescent volcanic cones at its summit, as already described by
D'Oriano (2010), are clearly displayed. The southwestern part of the summit (comprising the video-surveyed area) arises to water depths between 600 and $900 \mathrm{~m}$ on average, while one single peak (volcanic cone) even has an elevation of up to $560 \mathrm{~m}$ (Fig. 2; note: shallowest water depth given in D'Oriano et al., 2010, is $645 \mathrm{~m}$ ). To the northeast, the summit gradually deepens to water depths between 900 and $1100 \mathrm{~m}$. Overall, the summit area of Coral Patch seamount covers an area of $\sim 200 \mathrm{~km}^{2}$ between 560 and $1100 \mathrm{~m}$ water depth. The southern flank is rather steep and is incised by several pronounced canyon-like structures. In contrast, the northern flank is characterised by a more gently dipping slope (Fig. 2).

More detailed information about topographical features present on Coral Patch seamount are derived from the topographic zonal seabed classification (Fig. 7). Considering the BTM products from a statistical point of view and taking into account the grids resolution, a total of nine classes were defined. Thereby, zonal classes 1-5 describe rather elevated topographical structures such as outcrops, ridges, boulders and pinnacles, whereas zonal classes 6-9 are ascribed to flat and extensive areas, including flat plains, broad slopes, and depressions of different size and origin (such as scours and gullies; for further details see Table 4).

The broad-scale zonal classification map reveals several distinct large patches defined as rock outcrop highs, local ridges, boulders and pinnacles (zonal classes 1-4), which 
concentrate on the southwestern and northeastern part of the summit of Coral Patch and along the edge of its upper southern flank (Fig. 7). The position of these patches apparently resemble distinct volcanic edifices as described by D'Oriano et al. (2010). Moreover, the video surveys conducted at the southwestern summit cover one of these patches (Fig. 7). Zonal classes comprising flat plains, broad slopes and depressions (zonal classes 6-9) are more common on the central summit and clearly dominate the northern flank (Fig. 7). The fine-scale zonal classification map shows a more complex and widespread distribution pattern of rock outcrop highs, local ridges and boulders (zonal classes 1-4) across the entire summit and southern flank, whereas flat plains and depressions show a similar distribution pattern. Overall, the fine-scale thematic map reveals the rather small-scale alternating pattern of elevated morphological structures (e.g., local ridges, outcrop highs) and depressions which is, for example, clearly displayed for the video-surveyed southwestern summit area (Fig. 8). Finally, zonal class 5 defined as flat ridge tops is clearly alternating with classes 1 and 4 (rock outcrop highs, local ridges on slopes) by comparing the fineand broad-scale zonal maps (Fig. 7).

\subsubsection{MBES backscatter, textural seabed classification}

The subsequent textural seabed classification is based on four classes describing the variation of substrate types of the seafloor on Coral Patch seamount (labelled as classes 1-4 in Figs. 7, 8; note: classes 5 and 6 were used to exclude data to gaps and artificially influenced areas due to strong reflection in the slant range area, respectively). According to the videobased classification (Table 2), the four textural seabed classes (or substrate components, SC; see Sect. 3.1.1) are interpreted as low-relief bedrock (SC-A) comprising smooth bedrock and large boulders (textural class 1), high-relief bedrock (SCB) composed of fractured bedrock, boulders and pinnacles (textural class 2), mixed sediment (SC-C) composed of soft sediment and gravel- to cobble-sized rocks (textural class 3 ), and soft sediment (textural class 4; SC-D; Figs. 7, 8). As already revealed during video analyses, a clear dominance of hard substrates (SC-A: $27 \%$, SC-B: $17 \%$, SC-C: $24 \%$ ) is also displayed by the textural seabed classification, whereas soft substrate (SC-D: $32 \%$ ) just accounts for approximately one third of the mapped area.

A direct comparison between the distribution of topographic features and substrate types as defined by the textural classification reveals that soft sediment (textural class 4; SCD) is mainly associated with depressions (zonal class 9) and to a minor degree with broad slopes (zonal class 7), whereas exposed bedrock (textural classes 1 and 2; SC-A, -B) mirrors the occurrence of outcrops, local ridges, boulders and pinnacles (zonal classes 1-5; Fig. 7). Overall, extended areas made up of soft sediment (textural class 1, SC-A) dominate the gently dipping northern flank of Coral Patch seamount as well as its lower southern flank. Thereby, soft sediment plains often seem to be interspersed or covered by larger rocks as expressed by the partly scattered distribution of mixed sediment (textural class 3; SC-C). At the easternmost summit some larger patches of soft sediment are displayed as well. However, overall the entire summit area seems to be dominated by exposed bedrock comprising smooth and fractured bedrock as well as large boulders. Finally, the distribution of exposed bedrock as defined by the textural classification, being a suitable habitat for scleractinian cold-water corals, match $\sim 85 \%$ of the in situ video observations of live coral occurrences, which can be treated as a measure for the reliability of the remote seabed classification (Fig. 8).

\subsection{Physical water mass properties}

A temperature and salinity $(T-S)$ plot of the CTD observation (station GeoB 12761; see Fig. 1 for position) obtained in close vicinity of Coral Patch seamount clearly shows the different water masses present in the area (down to $2500 \mathrm{~m}$ water depth; Fig. 9). From the surface down to greater depths these are: the upper surface layer, the North Atlantic Central Water (NACW), the Mediterranean Outflow Water (MOW), the Antarctic Intermediate water (AAIW), and the North Atlantic Deep Water (NADW).

The vertical CTD profile shows that surface waters with high turbidity values correspond to chlorophyll maxima in the upper $50 \mathrm{~m}$ of the water column, indicating large amounts of fresh particles. In addition, highest values for temperature $\left(17.6^{\circ} \mathrm{C}\right)$, salinity $(36.55)$ and oxygen content $\left(4.7 \mathrm{~mL} \mathrm{~L}^{-1}\right)$ characterise the surface waters with all three parameters gradually decreasing with increasing depth, thereby the steepest gradient is recognised between 150 and $500 \mathrm{~m}$ depth (Fig. 9). A clear rise in salinity and (to a lesser degree) in temperature accompanied by a decrease in oxygen content between $600 \mathrm{~m}$ and $\sim 1420 \mathrm{~m}$ water depth is interpreted to reflect the presence of MOW, this interval coincides with a temperature range of 8.5 to $11.2^{\circ} \mathrm{C}$, a salinity range of 35.58 to 36.01 , and a range in oxygen content of 3.3 to $3.9 \mathrm{~mL}, \mathrm{~L}^{-1}$ (Fig. 9). The southwestern summit of Coral Patch seamount which extends to a water depth of up to $560 \mathrm{~m}$ (corresponding to one single peak, the summit on average covers a depth range of 600-900 m; see Fig. 2) is directly influenced by the upper part of the MOW. Below $1420 \mathrm{~m}$ water depth (down to $2500 \mathrm{~m}$ ), temperature and salinity gradually decrease again, whereas oxygen content increases towards values that were found for the surface waters. No signs for the existence of nepheloid layers were detected as the turbidity values remain very low throughout the water column (Fig. 9).

\section{Discussion}

\subsection{Sedimentological and morphological features}

During video observation, a clear dominance of exposed bedrocks having a smooth or rugged appearance was 
observed for the southwestern top of Coral Patch seamount (Fig. 3). In addition, the hydroacoustic seabed classification reveals that even the entire ENE-WSW elongated summit of the seamount is dominated by hard substrate (Fig. 7). However, areas with mixed and soft sediments are more frequent on the easternmost part of the summit and on the lower southern flank, and clearly dominate the northern flank (Fig. 7). This finding is confirmed by a former study by Moskalenko and Kogan (1995) based on seismic data. The authors describe the northern flank of Coral Patch seamount to be entirely covered by sediment. They further assume that the summit is covered by a thick (approximately $1 \mathrm{~km}$ ) stratified complex of sedimentary deposits. However, the latter assumption might partly account for the easternmost part of the summit, but not for its shallower southwestern top area as revealed by video observation and textural classification (Figs. 3, 7). The rather limited occurrence of mixed and soft sediments on the top of Coral Patch seamount might be explained by locally enhanced currents at the seamount's summit that inhibits the deposition of sediments and/or causes a pronounced re-mobilisation of deposited sediment layers (see also Duineveld et al., 2004: eastern top of Galicia Bank; Sánchez et al., 2008: Le Danois Bank). Current-induced ripples, found in low number during video observation (Fig. 3), and distinct current-scoured depressions, classified in the fine-scale zonal thematic map (Fig. 7), are clear evidence for high current speeds.

Although surface sediment samples are lacking it is assumed that due to the remoteness of Coral Patch from any continental sediment input, the soft sediment is composed of bioclastic sands which are formed by the shells of pelagic and benthic organisms. Rock samples (lava blocks) collected from the western summit of Coral Patch showed fissures in-filled or even cemented by lithified sedimentary carbonates also documenting that Coral Patch is today acting as an terrigenous-starved seamount (D'Oriano et al., 2010).

\subsection{Environmental controls on the occurrence of benthic megafauna}

The top area of Coral Patch seamount is clearly dominated by exposed bedrocks (Figs. 3, 7) and, hence, would offer suitable and large habitat area for the settlement of various important benthic organisms. However, at least the benthic megafauna of the southwestern summit area, having been subject to video observation, shows a rather scarce occurrence (Figs. 3, 4). In particular, cold-water corals (including framework-building scleractinians, large erect antipatharians, and gorgonians), which are known to act as biogenic habitats and host a broad variety of associated species (more than 1300 species; see Roberts et al., 2006), show a rather sporadic abundance on this part of the seamount's summit.

Several factors can reduce recruitment of benthic fauna and, thus, may account for such a pattern found on Coral Patch seamount including geographic isolation and un- favourable environmental conditions with respect to physical water mass properties and eutrophication. Coral Patch seamount has a clear geographic isolation with respect to its distance from mainland (i.e., shelf, continental margin) and from other seamounts (except from Ampère seamount, which is directly connected to its western edge; Fig. 1). Therefore, dispersal is the sole process by which benthic life can colonise the seamount (Gofas, 2007) and, thus, may restrict colonisation of the seamount to species that produce only long-lived larvae such as cold-water corals (Clark et al., 2010 and references therein).

Even more significant are unfavourable environmental conditions that reduce recruitment. Unfortunately, for the majority of taxa knowledge of environmental limits is still incomplete (Freiwald et al., 2004; Clark et al., 2006). For the important group of cold-water corals, the most comprehensive dataset to date exists for the cosmopolitan reefforming species Lophelia pertusa, which has also been identified, though in very low number, to be present on Coral Patch seamount (Figs. 3, 4). Based on its present-day distribution in the NE Atlantic it has been found that this species prefers specific physico-chemical boundary conditions such as a temperature range of 4 to $13.8^{\circ} \mathrm{C}$, a salinity range of 31.7 to 38.8 , dissolved oxygen levels that range from 2.6 to $7.2 \mathrm{~mL} \mathrm{~L}^{-1}$ (Freiwald et al., 2004; Roberts et al., 2006; Dodds et al., 2007; Davies et al., 2008), and a density of $\left(\sigma_{\Theta}\right)=27.5 \pm 0.15 \mathrm{~kg} \mathrm{~m}^{-3}$ although the latter is solely proved for the Norwegian and Celtic margins (Dullo et al., 2008). Water mass properties (temperature, salinity, oxygen content) measured in close vicinity to Coral Patch seamount (Fig. 9) fit well into these defined environmental thresholds. Although it has to be mentioned that data on physical water mass parameters derived from just one single CTD cast needs to be considered with caution as no spatial or temporal variability is resolved.

Another essential requirement for the development of healthy and sustained ecosystems in the deep-sea is the supply of nutrients and food particles by currents to the filterand suspension-feeding benthic organisms. The amount of available food in turn is directly linked to primary production in the surface waters. Indeed, for the most prominent cold-water corals species L. pertusa it has been found that it prefers high-quality organic matter produced in the photic zone of the water column (Duineveld et al. 2004; Kiriakoulakis et al., 2005; Duineveld et al. 2007). A study from the NE Atlantic revealed a dietary preference of Lophelia on (phyto)detritus (72\%), whereas only a small fraction derived from zooplankton (van Oevelen et al., 2009). In contrast, studies by Dodds et al. (2009) and Carlier et al. (2009), considering cold-water coral sites in the NE and NW Atlantic and in the Mediterranean Sea, identified zooplankton as the main food component. However, Coral Patch seamount is situated well inside the North Atlantic subtropical gyre (Stramma, 2001) and, thus, under the influence of oligotrophic conditions, meaning the content of dissolved 
nutrients and, thus, primary production in the surface waters is low as visible in satellite derived data (Behrenfeld et al., 2005). At first glance, the observation of large fish aggregation on Coral Patch seamount (Fig. 3) seems to be contradictory to the oligotrophic conditions in the area which might be one possible explanation for the scarce occurrence of benthic fauna. However, evidence for a relation between enhanced primary production and high concentrations of fish over seamounts is sparse (see Rogers et al., 1994). A seamount ecosystem model from the NE Atlantic revealed that local primary productivity enhancement alone cannot sustain large aggregations of seamount fishes (Morato et al., 2009). Instead the model results support the so-called "feedrest" theory which proposes that the rugged topography of a seamount provides ample shelter for fish, while the fishes only emerge from shelter to feed quickly somewhere around the seamount, and then retreat back to rest (Tseytlin, 1985; Genin, 2004; Morato et al., 2009). Indeed, the partly rugged topography of Coral Patch seamount (SC-B; see Figs. 3, 7, 8) might provide appropriate shelter for fish to rest in between periods seeking for food. In addition, during video survey a large resting aggregation of Hoplostethus mediterraneus was observed at the southwestern summit of the seamount (Fig. 5j).

Nevertheless, even under conditions of low primary productivity in the surface waters, the interplay between the seamount's topography and flow-driven mechanisms can locally enhance productivity that in turn causes increased biomass to accumulate in a relatively small space (Genin, 2004). Various mechanisms have been identified that may enhance and transport food particles to sessile benthic organisms in intermediate to deep water depths. These include internal waves and tides causing local resuspension, and nepheloid layers forming an important pathway for lateral transport (White et al., 2005; Duineveld et al., 2007; Davies et al., 2009). In addition, as seamounts act as obstacles for ocean currents, upwelling may occur on their upstream side, thereby nutrient-rich waters are transported upwards. Moreover, under a steady and strong current regime even a Taylor column may develop above the seamount's summit having a trapping effect for nutrients and food particles (Chapman and Haidvogel, 1992; White et al., 2005, 2007 and references therein).

Unfortunately, no appropriate data are available to directly prove if Coral Patch seamount is impacted by such currenttopography-induced flow phenomena. However, for the adjacent Ampère seamount some evidence for slight upwelling at its southern flank has been indicated (Kaufmann, 2005). The Great Meteor bank situated south of the Azores is one of the largest seamounts in the NE Atlantic with a wide plateau of $\sim 1500 \mathrm{~km}^{2}$ developed between $400 \mathrm{~m}$ and its summit at $275 \mathrm{~m}$ water depth. There is some evidence for the formation of a (weak) Taylor cap. Nevertheless, no significant upwelling into the nutrient-depleted surface layers and also no significant enhancement of phytoplankton biomass could be detected (Beckmann and Mohn, 2002; Kaufmann, 2005). Comparable to Coral Patch seamount also for this seamount it has been found that the benthic fauna is relatively poor in terms of abundance and species diversity (Bartsch, 2008). It might be speculated that a seamount characterised by a wide and elongated summit, as found for Great Meteor bank and Coral Patch, possibly inhibits the development of an efficient Taylor column and, thus, a sustained enrichment of nutrients and food particles. Another example, for an elongated seamount that has been intensely studied during recent years is the Le Danois bank in the Bay of Biscay (Cartes et al., 2007a, b; Sánchez et al., 2008; González-Pola et al., 2012). Its flat top arises to a water depth of $430 \mathrm{~m}$ and, comparable to Coral Patch seamount, it is characterised by a scarce sediment cover and numerous rocky outcrops probably related to strong currents (Sánchez et al., 2008). However, in contrast to the geographically isolated Coral Patch seamount and Great Meteor bank, this seamount hosts a rather diverse benthic fauna which is attributed to its close connection to the adjacent Cantabrian shelf incised by two large canyons. The canyons increase the flux of organic matter which is transported in bottom nepheloid layers across the continental shelf to the seamount and the deep sea (Sorbe, 1999).

\subsection{Impact of fisheries on benthic faunal communities}

Another explanation for the rather scarce occurrence of benthic organisms on the Coral Patch seamount might be attributed to the impact of fishing activities. Many commercially important fish species (i.e., tunas, mackerels, orange roughy) are associated to seamounts making them very attractive to fisheries (Morato and Pauly, 2004; Pitcher et al., 2007; Clark et al., 2010; Morato et al., 2010). Since the 1970s, extensive trawling on seamounts led to the overexploitation or even depletion of numerous fish species (Morato et al., 2006; Clark et al., 2007; Sissenwine and Mace, 2007; Pitcher et al., 2010). Also on Coral Patch seamount important commercial fish species (see Table 3; Fig. 4h-k) were observed in partly high numbers which make this seamount a potential fishing target. While no trawl marks were identified during video observation, most probably related to the dominance of hard substrate at the southwestern top area of Coral Patch seamount which would inhibit any imprint, lost long lines were frequently observed during video observation (Figs. 3-5). Historical data on fishery catches derived from other seamounts in the surrounding area of Coral Patch seamount (comprising seamounts between Madeira and $\mathrm{Ca}-$ nary Islands and south of the Azores) revealed enhanced fishery catches during the early 1970s (Clark et al., 2007; Pitcher et al., 2010).

Fishing not just threatens fish stocks, it also has a negative effect on the benthic community colonising seamounts (Koslow et al., 2000, 2001; Clark and Rowden, 2009). Coldwater corals which are important components of the benthic seamount fauna are particularly vulnerable due to their 
longevity of hundreds to thousands of years (i.e., gorgonians, antipatharians) in combination with very slow growth rates in the range of $\mu \mathrm{m}$ to $\mathrm{mm}$ per year as indicated for antipatharians, gorgonians and scleractinians (Adkins et al., 2004; Roark et al., 2006; Orejas et al., 2011). Hence, recovery from any disturbance or damage takes several years or is even irreversible (Williams et al., 2010). Moreover, framework-building scleractinians (e.g., Lophelia pertusa) and large erect antipatharians and gorgonians form complex biogenic habitats as they provide refugia for a diverse mobile fauna (i.e., crustaceans, echinoids, fish) and attachment sites for a great variety of sessile filter-feeders (i.e., sponges, crinoids, brachiopods) (Roberts et al., 2006; Rogers et al., 2007; O'Hara et al., 2008). However, only few studies examined the effect of fishing on benthic faunal communities in detail, in particular, regarding intermediate to deep seamount ecosystems. For the Le Danois bank in the Bay of Biscay, it is assumed that high fishing pressure that existed in the past had great consequences on the abundance of vulnerable and low resilience sessile organisms such as scleractinian coldwater corals, gorgonians and sponges (Sánchez et al., 2008). On an Australian seamount that had been heavily trawled, it has been found that cold-water corals showed no signs of recolonisation even 10 years after trawling had ceased and that the loss of coral habitat resulted in declines in diversity and density of other macrobenthos (Althaus et al., 2009). Thus, this study strikingly demonstrates how severely fishing impacts the entire ecosystem of a seamount.

On the southwestern summit of Coral Patch seamount several coral thickets were identified to be entangled with fishing lines (Figs. 3, 4). Thereby, some of the thickets showed clear evidence that there were transported over a certain distance as obvious fractures mark their skeleton. Moreover, one thicket was even looking relatively fresh with few live polyps and also the line around the thicket showed no signs of colonisation or alteration (Fig. 4c) emphasising that Coral Patch is still influenced by fishing activities. Finally, the rare and isolated occurrences of small-sized live coral colonies are mainly associated to high-relief bedrock (SC-B; Fig. 3) thereby the rough area might offer natural refugia (small caves, depressions etc.) which are inaccessible to trawls or other fishing gears.

\section{Conclusions}

The environment of isolated and intermediate to deep seamounts is rather difficult to explore due to their remote position in combination with a lack of appropriate sampling and observation tools. Only since the late 1990s, along with advances in marine technology, the application of sophisticated video-supported scientific equipment such as ROVs allows to obtain direct in situ information about the characteristics of a seamount by visual observation and dedicated sampling. However, also video observation has a certain lim- itation with respect to the often huge dimension of seamounts and the large surface area that needs to be explored to gain a complete picture of the biological and sedimentological characteristics. Therefore, hydroacoustic seabed classification, verified by in situ video observations, provides a useful tool to image characteristics of the seafloor over large areas and, thus, can be used to predict suitable habitat for benthic seamount fauna. In particular with respect to future scientific campaigns, this information will be indispensable to create a dedicated and successful monitoring and sampling programme to obtain the complete range of habitat types and benthic communities present on a seamount. And even more important, such data will be essential to assess the vulnerability of a deep-sea ecosystem to develop appropriate and sustained conservation and management strategies. Nevertheless, the results of our study show that solely with a combination of both methods, a satisfactory approach to describe the diverse characteristics of a seamount ecosystem can be derived.

To sum up, the present case study of Coral Patch seamount provides for the first time detailed information about its sedimentological and biological characteristics. The video surveys being restricted to a rather small area on the southwestern summit as well as the hydroacoustic seabed classification covering an area of $560 \mathrm{~km}^{2}$ showed that exposed hard substrates (often associated to locally elevated morphological structures) are common on the entire summit area of Coral Patch seamount and, thus, may offer suitable habitat for many sessile benthic organisms. Nevertheless, the video data reveal that at least its southwestern top is characterised by a low number of benthic organisms. In particular, coldwater corals, which form important biogenic habitat for other megabenthos, are apparently rare and just comprise very isolated and small-sized live colonies of the species Lophelia pertusa and Madrepora oculata. This might be attributed to the oligotrophic conditions in the area in combination with a lack of appropriate mechanisms (upwelling, Taylor column, internal tides and waves) supplying sufficient food from other sources to the sessile suspension-feeders. In addition, it cannot be excluded that this pattern might also result from intense fishing activities, evident on Coral Patch seamount by several findings of fishing lines and destroyed coral thickets entangled in these lines, although more quantified data are needed to confirm this assumption. Benthic seamount communities including cold-water corals are extremely longlived and grow very slowly making them particularly vulnerable to the impact of fishing. Therefore, biogenic habitats that may accumulate over thousands of years can be rapidly reduced by fishing, whereas recovery from this severe destruction may span decades or even centuries. In addition, it is uncertain whether systems will ever recover to their original ecological structure. 
Acknowledgements. The research leading to these results has received funding from the European Community's Seventh Framework Programme (FP7/2007-2013) under the HERMIONE project, grant agreement no. 226354, and under the CoralFISH project, grant agreement no. 213144. In addition, this study was partially funded by LOEWE BiK-F Project A3.10. We thank the officers and crew of the R/V PELAGIA, the Royal NIOZ staff and technicians, the MARUM ROV CHEROKEE team, and the scientific crew for on-board assistance during cruise 64PE284 (2008). In this context, we appreciate the most valuable support of the Royal NIOZ, in particular, the Marine Research Facilities coordinator Marieke J. Rietveld, and the barter agreement that rules the exchange of ship's time within the European fleet of research vessels. The cruise was supported by the Deutsche Forschungsgemeinschaft (DFG) through the grants HE 3412/10 and HE 3412/11, and through the DFG-Research Center/Cluster of Excellence "The Ocean in the Earth System". Helmut Zibrowius (scleractinians, stylasterids), Michael Tuerkay (crustaceans), and Imants Priede (fishes) are kindly acknowledged for their support in taxonomic determination. We further thank André Freiwald for providing faunal content information of two grab samples collected during R/V VICTOR HENSEN cruise VH97 (1997), and Jürgen Titschack for plotting the UNEP-WCME-based cold-water coral distribution map for the NE Atlantic seamounts. Finally, we appreciate the comments of an anonymous reviewer and of Philippe Blondel, which greatly improved the manuscript.

Edited by: R. Danovaro

\section{References}

Adkins, J. F., Henderson, G. M., Wang, S.-L., O'Shea, S., and Mokadem, F.: Growth rates of the deep-sea scleractinia Desmophyllum cristagalli and Enallopsammia rostrata, Earth Planet. Sci. Lett., 227, 481-490, 2004.

Althaus, F., Williams, A., Schlacher, T. A., Kloser, R. J., Green, M. A., Barker, B. A., Bax, N. J., Brodie, P., and SchlacherHoenlinger, M. A.: Impacts of bottom trawling on deep-coral ecosystems of seamounts are long-lasting, Mar. Ecol.-Prog. Ser., 397, 279-294, 2009.

Auster, P. J., Moore, J., Heinonen, K. B., and Watling, L.: A habitat classification scheme for seamount landscapes: assessing the functional role of deep-water corals as fish habitat, in: Cold-water Corals and Ecosystems, edited by: Freiwald, A. and Roberts, J. M., Springer, Heidelberg, 761-769, 2005.

Bartsch, I.: Notes on ophiurids from the Great Meteor Seamount (Northeastern Atlantic) (Echinodermata, Ophiuridea), Spixiana, 31, 233-239, 2008.

Beckmann, A. and Mohn, C.: The upper ocean circulation at Great meteor Seamount. Part II: Retention potential of the seamountinduced circulation, Ocean Dynam., 52, 194-204, 2002.

Behrenfeld, M. J., Boss, E., Siegel, D. A., and Shea, D. M.: Carbon-based ocean productivity and phytoplankton physiology from space, Global Biogeochem. Cy., 19, GB1006, doi:10.1029/2004GB002299, 2005.

Bergstad, O. A., Falkenhaug, T., Astthorsson, O. S., Byrkjedal, I., Gebruk, A. V., Piatkowski, U., Priede, I. G., Santos, R. S., Vecchione, M., Lorance, P., and Gordon, J. D. M.: Towards improved understanding of the diversity and abundance patterns of the mid- ocean ridge macro- and megafauna, Deep-Sea Res. Pt. II, 55, 15, 2008.

Blondel, P.: Seabed classification of ocean margins, in: Ocean Margin Systems, edited by: Wefer, G., Billet, D., Hebbeln, D., Jorgensen, B. B., Schlüter, M., and van Weering, T. C. E., Springer, Berlin, Heidelberg, 125-141, 2002.

Blondel, P. and Gómez Sichi, O.: Textural analyses of multibeam sonar imagery from Stanton Banks, Northern Ireland continental shelf, Appl. Acoust., 70, 1288-1297, 2009.

Blondel, P. and Murton, B. J.: Handbook of seafloor sonar imagery, Praxis-Wiley \& Son, 314 pp., 1997.

Brown, C. J. and Blondel, P.: Developments in the application of multibeam sonar backscatter for seafloor habitat mapping, Appl. Acoust., 70, 1242-1247, 2009.

Buchanan, J. Y.: On Oceanic Shoals discovered in the S. S. Dacia in October 1883, P. Roy. Soc. Edinb., 13, 428-443, 1885.

Buforn, E., Udias, A., and Colombas, M. A.: Seismicity, source mechanism and tectonics of the Azores-Gibraltar plate boundary, Geophysics, 152, 89-118, 1988.

Carlier, A., Le Guilloux, E., Olu-Le Roy, K., Sarrazin, J., Mastrototaro, F., Taviani, M., and Clavier, J.: Trophic relationships in a deep Mediterranean cold-water coral bank (Santa Maria di Leuca, Ionian Sea), Mar. Ecol.-Prog. Ser., 397, 125-137, 2009.

Cartes, J. E., Huguet, C., Parra, S., and Sanchez, F.: Trophic relationships in deep-water decapods of Le Danois bank (Cantabrian Sea, NE Atlantic): Trends related with depth and seasonal changes in food quality and availability, Deep-Sea Res. Pt. I, 54, 1091-1110, 2007a.

Cartes, J. E., Serrano, A., Velasco, F., Parra, S., and Sánchez, F.: Community structure and dynamics of deep-water decapod assemblages from Le Danois Bank (Cantabrian Sea, NE Atlantic): Influence of environmental variables and food availability, Prog Oceanogr., 75, 797-816, 2007b.

Chapman, D. C. and Haidvogel, D. B.: Formation of Taylor caps over a tall isolated seamount in a stratified ocean, Geophys. Astro. Fluid, 64, 31-65, 1992.

Christiansen, B. and Wolff, G.: The oceanography, biogeochemistry and ecology of two NE Atlantic seamounts: The OASIS project, Deep-Sea Res. Pt. II, 56, 2579-2581, 2009.

Clark, M. R. and Rowden, A. A.: Effect of deepwater trawling on the macroinvertebrate assemblages of seamounts on the Chatham Rise, New Zealand, Deep-Sea Res. Pt. I, 56, 1540-1554, 2009.

Clark, M. R., Tittensor, D., Rogers, A. D., Brewin, P., Schlacher, T. A., Rowden, A. A., Stocks, K., and Consalvey, M.: Seamount, deep-sea corals and fisheries: vulnerability of deep-sea corals to fishing on seamounts beyond areas of national jurisdication, UNEP-WCMC, Biodiversity Series No. 25, Cambridge, UK, 80 pp., 2006.

Clark, M. R., Vinnichenko, V. I., Gordon, J. D. M., Beck-Bulat, G. Z., Kukharev, N. N., and Kakora, A. F.: Large-scale distant-water trawl fisheries on seamounts, in: Seamounts: Ecology, Fisheries and Conservation, edited by: Pitcher, T. J., Morato, T., Hart, P. J. B., Clark, M. R., Haggan, N., and Santos, R. S., Blackwell Publishing, Oxford, UK, 363-401, 2007.

Clark, M. R., Rowden, A. A., Schlacher, T., Williams, A., Consalvey, M., Stocks, K. I., Rogers, A. D., O'Hara, T. D., White, M., Shank, T. M., and Hall-Spencer, J. M.: The ecology of seamounts: Structure, function, and human impacts, Annu. Rev. Mar. Sci., 2, 253-278, 2010. 
Coiras, E., Lo Iacono, C., Gràcia, E., and Danobeitia, J.: Automatic segmentation of multi-beam data for predictive habitat mapping of benthic habitats on the Chella Seamount (north-eastern Alboran Sea, western Mediterranean), IEEE J. Sel. Top. Appl., 4, 809-813, 2011.

D’Oriano, F., Angeletti, L., Capotondi, L., Laurenzi, M. A., López Correa, M., Taviani, M., Torelli, L., Trua, T., Vigliotti, L., and Zitellini, N.: Coral Patch and Ormonde seamounts as a product of the Madeira hotspot, Eastern Atlantic Ocean, Terra Nova, 22, 494-500, 2010.

Davies, A. J., Wisshak, M., Orr, J. C., and Roberts, J. M.: Predicting suitable habitat for the cold-water coral Lophelia pertusa (Scleractinia), Deep-Sea Res. Pt. I, 55, 1048-1062, 2008.

Davies, A. J., Duineveld, G., Lavaleye, M., Bergman, M. J., van Haren, H., and Roberts, J. M.: Downwelling and deep-water bottom currents as food supply mechanisms to the cold-water coral Lophelia pertusa (Scleractinia) at the Mingulay Reef Complex, Limnol. Oceanogr., 54, 620-629, 2009.

Dodds, L. A., Roberts, J. M., Taylor, A. C., and Marubini, F.: Metabolic tolerance of the cold-water coral Lophelia pertusa (Scleractinia) to temperature and dissolved oxgen change, J. Exp. Mar. Biol. Ecol., 349, 205-214, 2007.

Dodds, L. A., Black, K. D., Orr, H., and Roberts, J. M.: Lipid biomarkers reveal geographical differences in food supply to the cold-water coral Lophelia pertusa (Scleractinia), Mar. Ecol.Prog. Ser., 397, 113-124, 2009.

Duineveld, G. C. A., Lavleye, M. S. S., and Berghuis, E. M.: Particle flux and food supply to a seamount cold-water coral community (Galicia Bank, NW Spain), Mar. Ecol.-Prog. Ser., 277, 13-23, 2004.

Duineveld, G. C. A., Lavaleye, M. S. S., Bergman, M. J. N., De Stigter, H., and Mienis, F.: Trophic structure of a cold-water coral mound community (Rockall Bank, NE Atlantic) in relation to the near-bottom particle supply and current regime, B. Mar. Sci., 81, 449-467, 2007.

Dullo, W.-C., Flögel, S., and Rüggeberg, A.: Cold-water coral growth in relation to the hydrography of the Celtic and Nordic European continental margin, Mar. Ecol.-Prog. Ser., 371, 165176, 2008.

Erdey-Heydorn, M. D.: An ArcGIS seabed characterization toolbox developed for investigating benthic habitats, Mar. Geod., 31, 318-358, 2008.

Etnoyer, P. J., Wood, J., and Shirley, T. C.: How large is the seamount biome?, Oceanography, 23, 206-209, 2010.

FGDC-CMECS: Coastal and Marine Ecological Classification Standard (FGDC-STD-018-2012), Federal Geographic Data Committee, 343 pp., 2012.

Fonseca, L. and Mayer, L.: Remote estimation of surficial seafloor properties through the application angular range analysis to multibeam sonar data, Mar. Geophys. Res., 28, 119-126, 2007.

Fonseca, L., Brown, C. J., Calder, B., Mayer, L., and Rzhanov, Y.: Angular range analysis of acoustic themes from Stanton Banks Ireland: A link between visual interpretation and multibeam echosounder angular signatures, Appl. Acoust., 70, 1298-1304, 2009.

Freiwald, A., Fosså, J. H., Grehan, A., Koslow, T., and Roberts, J. M.: Cold-water Coral Reefs, Biodiversity Series 22, UNEPWCMC, Cambridge, UK, 84 pp., 2004.
Gage, J. D., Roberts, J. M., Hartley, J. P., and Humphery, J. D.: Potential impacts of deep-sea trawling on the benthic ecosystem along the northern European continental margin: a review, Am. Fish. S. S., 41, 503-517, 2005.

Geldmacher, J. and Hoernle, K.: The 72 Ma geochemical evolution of the Madeira Hotspot (eastern North Atlantic); recycling of Paleozoic ( $\leq 500 \mathrm{Ma}$ ) oceanic lithosphere, Earth Planet. Sci. Lett., $183,73-92,2000$.

Genin, A.: Bio-physical coupling in the formation of zooplankton and fish aggregations over abrupt topographies, J. Marine Syst., 50, 3-20, 2004.

Genin, A., Dayton, P. K., Lonsdale, P. F., and Spiess, F. N.: Corals on seamount peaks provide evidence of current acceleration over deep-sea topography, Nature, 322, 59-61, 1986.

Gofas, S.: Rissoidae (Mollusca: Gastropoda) from the northeast Atlantic seamounts, J. Nat. Hist., 41, 779-885, 2007.

González-Pola, C., Díaz del Río, G., Ruiz-Villarreal, M., Sánchez, R. F., and Mohn, C.: Circulation patterns at Le Danois Bank, an elongated shelf-adjacent seamount in the Bay of Biscay, DeepSea Res. Pt. I, 60, 7-21, 2012.

Greene, H. G., Yoklavich, M. M., Starr, R. M., O’Connell, V. M., Wakefield, W. W., Sullivan, D. E., McRea, J. E., and Cailliet, G. M.: A classification scheme for deep seafloor habitats, Oceanol. Acta, 22, 663-678, 1999.

Grigg, R. W., Malahoff, A., Chave, E. H., and Landahl, J.: Seamount benthic ecology and potential environmental impact from manganese crust mining in Hawaii, in: Seamounts, Islands, and Atolls, edited by: Keating, B. H., Fryer, P., Batiza, R., and Boehlert, G. W., American Geophysical Union, Washington, DC, 379-390, 1987.

Guinan, J., Grehan, A., Dolan, M. F. J., and Brown, C. N.: Quantifying relationships between video observations of cold-water coral cover and seafloor features in Rockall Trough, west of Ireland, Mar. Ecol.-Prog. Ser., 375, 125-138, 2009.

Guisan, A. and Zimmermann, N. E.: Predictive habitat distribution models in ecology, Ecol. Model., 135, 147-186, 2000.

Halbach, P., Maggiulli, M., Kuhn, T., Halbach, M., Schulz, A., and Szemeitat, A.: Second annual report of the MARFLUX Project "Biogeochemical fluxes in the Ocean-sediment environment" (MAST 0022-C), Free University of Berlin, Berlin, 27 pp., 1992.

Hamilton, L. J.: Acoustic seabed segmentation for echosounders through direct statistical clustering of seabed echoes, Cont. Shelf Res., 31, 2000-2011, 2011.

Hatzky, J.: Physiography of the Ampère Seamount in the Horseshoe Seamount chain off Gibraltar, in: Sound Images of the Ocean in Research and Monitoring, edited by: Wille, P. C., Springer, Berlin-Heidelberg, 131-132, 2005.

Hebbeln, D., Wienberg, C., Beuck, L., Boom, L., Cunha, M., Dimmler, W., Eisele M., El Frihmat, Y., Fink, H. G., Groenewegen, R., Löffler, S., López, N., Lutz, M., Meyer-Schack, B. and Nowald, N.: Report and preliminary results of RV PELAGIA Cruise 64PE284 "Cold-Water Corals in the Gulf of Cádiz and on Coral Patch Seamount (NE Atlantic)", Portimao-Portimao, 18 February-9 March 2008, University of Bremen, Germany, 90 pp., 2008.

Jackson, D. R., Winebrenner, D. P., and Ishimaru, A.: Application of the composite roughness model to high-frequency bottom backscatter, J. Acoust. Soc. Am., 79, 1410-1422, 1986. 
Kaufmann, M.: Der Einfluss von Seamounts auf die klein- und mesoskalige Verteilung des Phytoplanktons im zentralen, subtropischen Nordostatlantik, Ph.D., Christian-AlbrechtsUniversität, Kiel, Germany, 2005.

Kiriakoulakis, K., Harper, E., and Wolff, G. A.: Lipids and nitrogen isotopes of two deep-water corals from the North-East Atlantic: initial results and implications for their nutrition, in: Cold-water Corals and Ecosystems, edited by: Freiwald, A. and Roberts, J. M., Springer, Berlin-Heidelberg, 715-729, 2005.

Kitchingman, A. and Lai, S.: Inferences of potential seamount locations from mid-resolution bathymetric data, in: Seamounts: Biodiversity and Fisheries, edited by: Morato, T. and Pauly, D., Fisheries Centre, University of British Columbia, Vancouver, 7-12, 2004.

Koslow, J. A.: Seamounts and the ecology of deep-Sea fisheries, Am. Scientist, 85, 168-176, 1997.

Koslow, J. A., Boehlert, G. W., Gordon, J. D. M., Haedrich, R. L., Lorance, P., and Parin, N.: Continental slope and deep-sea fisheries: implications for a fragile ecosystem, J. Mar. Sci., 57, 548557,2000

Koslow, J. A., Gowlett-Holmes, K., Lowry, J. K., O’Hara, T., Poore, G. C. B., and Williams, A.: Seamount benthic macrofauna off southern Tasmania: community structure and impacts of trawling, Mar. Ecol.-Prog. Ser., 213, 111-125, 2001.

Kostylev, V. E., Todd, B. J., Fader, G. B. J., Courtney, R. C., Cameron, G. D. M., and Pickrill, R. A.: Benthic habitat mapping on the Scotian shelf based on multibeam bathymetry, surficial geology and sea floor photographs, Mar. Ecol.-Prog. Ser., 219, 121-137, 2001

Lundblad, E., Wright, D. J., Miller, J., Larkin, E. M., Rinehart, R. W., Battista, T., Anderson, S. M., Naar, D. F., and Donahue, B. T.: A benthic terrain classification scheme for American Samoa, Mar. Geod., 29, 89-111, 2006.

Lurton, X.: An Introduction to Underwater Acoustics: Principles and Applications, Springer, Chichester, 347 pp., 2002.

Martin, B. and Christiansen, B.: Distribution of zooplankton biomass at three seamounts in the NE Atlantic, Deep-Sea Res. Pt. II, 56, 2671-2682, 2009.

McClain, C. R.: Seamounts: identity crisis or split personality?, J. Biogeogr., 34, 2001-2008, 2007.

Menard, H. W.: Marine Geology of the Pacific, McGraw-Hill, New York, 1964.

Mironov, A. N., Gebruk, A. V., and Southward, A. J.: Biogeography of the North Atlantic Seamounts, KMK Scientific Press Ltd., Moscow, 2006.

Micallef, A., Le Bas, T. P., Huvenne, V. A. I., Blondel, P., Hühnerbach, V., and Deidun, A.: A multi-method approach for benthic habitat mapping of shallow coastal areas with highresolution multibeam data, Cont. Shelf Res., 39-40, 14-26, 2012.

Morato, T. and Pauly, D.: Seamounts: Biodiversity and fisheries, Fisheries Centre Research Reports, Vol. 12, Fisheries Centre, University of British Columbia, Canada, 78 pp., 2004.

Morato, T., Cheung, W. W. L., and Pitcher, T. J.: Vulnerability of seamount fish to fishing: fuzzy analysis of life-history attributes, J. Fish Biol., 68, 209-221, 2006.

Morato, T., Bulman, C., and Pitcher, T. J.: Modelled effects of primary and secondary production enhancement by seamounts on local fish stocks, Deep-Sea Res. Pt. II, 56, 2713-2719, 2009.
Morato, T., Hoyle, S. D., Allain, V., and Nicol, S. J.: Seamounts are hotspots of pelagic biodiversity in the open ocean, P. Natl. Acad. Sci. USA, 107, 9707-9711, 2010.

Morato, T., Kvile, K. Ø., Taranto, G. H., Tempera, F., Narayanaswamy, B. E., Hebbeln, D., Menezes, G. M., Wienberg, C., Santos, R. S., and Pitcher, T. J.: Seamount physiography and biology in the north-east Atlantic and Mediterranean Sea, Biogeosciences, 10, 3039-3054, doi:10.5194/bg-10-3039-2013, 2013.

Moskalenko, V. N. and Kogan, L. I.: Sedimentary cover structure in the eastern Azores-Gibraltar zone (the Horseshoe Basin), Geotectonics, 28, 334-343, 1995.

Mulhearn, P. J.: Modelling acoustic backscatter from near-normal incidence echo sounders - Sensitivity analysis of the Jackson model, DSTO, Maritime Operations Division, Aeronautical and Maritime Research Laboratory, Melbourne, Australia, 35 pp., 2000.

O'Hara, T. D., Rowden, A. A., and Williams, A.: Cold-water coral habitats on seamounts: Do they have a specialist fauna?, Divers. Distrib., 14, 925-934, 2008.

Orejas, C., Ferrier-Pagès, C., Reynaud, S., Gori, A., Beraud, E., Tsounis, G., Allemand, D., and Gili, J. M.: Long-term growth rates of four Mediterranean cold-water coral species maintained in aquaria, Mar. Ecol.-Prog. Ser., 429, 57-65, 2011.

Pickrill, R. A. and Tood, B. J.: The multiple roles of acoustic mapping in integrated ocean management, Canadian Atlantic continental margin, Ocean Coast. Manage., 46, 601-614, 2003.

Pitcher, T. J., Morato, T., Hart, P. J. B., Clark, M. R., Haggan, N., and Santos, R. S.: Seamounts: Ecology, Fisheries, and Conservation, Blackwell Fisheries and Aquatic Resources Series, Vol. 12, Blackwell Publishing, Oxford, 527 pp., 2007.

Pitcher, T. J., Clark, M. R., Morato, T., and Watson, R.: Seamount fisheries: Do they have a future?, Oceanography, 23, 134-144, 2010.

Pourtalès de, L. F.: Reports on the dredging operations of the U.S. Coast Survey Steamer "Blake." Corals and crinoids, Bulletin of the Museum of Comparative Zoology at Harvard College, 5, 213-216, pl. 2., 1878.

Probert, P. K., McKnight, D. G., and Grove, S. L.: Benthic invertebrate bycatch from a deep-water trawl fishery, Chatham Rise, New Zealand, Aquat. Conserv., 7, 27-40, 1997.

Richer de Forges, B., Koslow, J. A., and Poore, G. C. B.: Diversity and endemism of the benthic seamount fauna in the southwest Pacific, Nature, 405, 944-947, 2000.

Roark, E. B., Guilderson, T. P., Dunbar, R. B., and Ingram, B. L.: Radiocarbon-based ages and growth rates of Hawaiian deep-sea corals, Mar. Ecol.-Prog. Ser., 327, 1-14, 2006.

Roberts, J. M., Brown, C. J., Long, D., and Bates, C. R.: Acoustic mapping using a multibeam echosounder reveals cold-water coral reefs and surrounding habitats, Coral Reefs, 24, 654-669, 2005.

Roberts, J. M., Wheeler, A. J., and Freiwald, A.: Reefs of the deep: The biology and geology of cold-water coral ecosystems, Science, 312, 543-547, 2006.

Rogers, A. D.: The biology of seamounts, Adv. Mar. Biol., 30, 305350, 1994.

Rogers, A. D., Baco, A., Griffiths, H., Hart, T., and Hall-Spencer, J. M.: Corals on seamounts, in: Seamounts: Ecology, Fisheries and Conservation, edited by: Pitcher, T. J., Morato, T., Hart, P. J. B., 
Clark, M. R., Haggan, N., and Santos, R. S., Wiley-Blackwell, Oxford, UK, 141-169, 2007.

Rowden, A. A., Dower, J. F., Schlacher, T. A., Consalvey, M., and Clark, M. R.: Paradigms in seamount ecology: fact, fiction and future, Mar. Ecol., 31, 226-241, 2010.

Samadi, S., Bottan, L., Macpherson, E., Richer de Forges, B., and Boisselier, M.-C.: Seamount endemism questioned by the geographical distribution and population genetic structure of marine invertebrates, Mar. Biol., 149, 1463-1475, 2006.

Sánchez, F., Serrano, A., Parra, S., Ballesteros, M., and Cartes, J. E.: Habitat characteristics as determinant of the structure and spatial distribution of epibenthic and demersal communities of Le Danois Bank (Cantabrian Sea, N. Spain), J. Marine Syst., 72, 64-86, 2008.

Schlacher, T. A., Williams, A., Althaus, F., and SchlacherHoenlinger, M. A.: High-resolution seabed imagery as a tool for biodiversity conservation planning on continental margins, Mar. Ecol., 31, 200-221, 2010.

Sissenwine, M. P. and Mace, P. M.: Can deep water fisheries be managed sustainably?, Report and Documentation of the Expert Consultation on Deep-Sea fisheries in the High Seas, FAO Fish., 836, 61-111, 2007.

Sorbe, J. C.: Deep-sea macrofaunal assemblages within the benthic boundary layer of the Cap-Ferret Canyon (Bay of Biscay, NE Atlantic ), Deep-Sea Res. Pt. II, 46, 2309-2329, 1999.

Staudigel, H., Koppers, A. A. P., Lavelle, J. W., Pitcher, T. J., and Shank, T. M.: Defining the word "seamount", Oceanography, 23, 20-21, 2010.

Stocks, K.: Seamount invertebrates: composition and vulnerability to fishing, in: Seamounts: biodiversity and fisheries, edited by: Morato, T., and Pauly, D., Fisheries Centre Research Reports, Vol. 12, Fisheries Centre, University of British Columbia, Vancouver, Canada, 17-24, 2004.

Stramma, L.: Current systems in the Atlantic Ocean, in: Encyclopedia of Ocean Sciences, edited by: Steele, J. H., Thorpe, S. A., and Turekian, K. K., Academic Press, London, 589-598, 2001.

Surugiu, V., Dauvin, J.-C., Gillet, P., and Ruellet, T.: Can seamounts provide a good habitat for polychaete annelids? Example of the northeastern Atlantic seamounts, Deep-Sea Res. Pt. I, 55, 15151531, 2008.

Tseytlin, V. B.: Energetics of fish populations inhabiting seamounts, Oceanography, 25, 237-239, 1985.

van Aken, H. M.: The hydrography of the mid-latitude Northeast Atlantic Ocean II: the intermediate water masses, Deep-Sea Res. Pt. I, 47, 789-824, 2000.

van Oevelen, D., Duineveld, G., Lavaleye, M., Mienis, F., Soetaert, K., and Heip, C. H. R.: The cold-water coral community as a hot spot for carbon cycling on continental margins: A food-web analysis from Rockall Bank (northeast Atlantic), Limnol. Oceanogr., 54, 1829-1844, 2009.

van Rein, H., Brown, C. J., Quinn, R., Breen, J., and Schoeman, D.: An evaluation of acoustic seabed classification techniques for marine biotope monitoring over broad-scales $\left(>1 \mathrm{~km}^{2}\right)$ and meso-scales $\left(10 \mathrm{~m}^{2}-1 \mathrm{~km}^{2}\right)$, Estuar. Coast Shelf S., 93, 336-349, 2011. von Rad, U.: Great Meteor and Josephine Seamounts (eastern North Atlantic): Composition and origin of bioclastic sands, carbonate and pyroclastic rocks, "Meteor"- Forschungsergebnisse, 19, 161, 1974.

Wessel, P., Sandwell, D. T., and Kim, S.-S.: The global seamount census, Oceanography, 23, 24-33, 2010.

White, J., Jegat, V., Van Lancker, V., Deleu, S., and Vanstaen, K.: Multibeam echo Sounders, in: Review of Standards and Protocols for Seabed Habitat Mapping. Mapping European Seabed Habitats (MESH), edited by: Coggan, R., Populus, J., White, J., Sheehan, K., Fitzpatrick, F., and Piel, S., Peterborough, UK, 5372, 2007.

White, M., Mohn, C., de Stigter, H., and Mottram, G.: Deep-water coral development as a function of hydrodynamics and surface productivity around the submarine banks of the Rockall Trough, NE Atlantic, in: Cold-water Corals and Ecosystems, edited by: Freiwald, A., and Roberts, J. M., Springer, Heidelberg, 503-514, 2005.

White, M., Bashmachnikov, I., Aristegui, J., and Martins, A.: Physical processes and seamount productivity, in: Seamounts: Ecology, Fisheries \& Conservation, edited by: Pitcher, T. J., Morato, T., Hart, P. J. B., Clark, M. R., Haggan, N., and Santos, R. S., Blackwell Publishing, Oxford, UK, 65-84, 2007.

Wienberg, C., Beuck, L., Heidkamp, S., Hebbeln, D., Freiwald, A., Pfannkuche, O., and Monteys, X.: Franken Mound - facies and biocoenosis mapping of a newly-discovered "carbonate mound" at the West Rockall Bank, NE-Atlantic, Facies, 54, 1-24, 2008.

Wienberg, C., Hebbeln, D., Fink, H. G., Mienis, F., Dorschel, B., Vertino, A., López Correa, M., and Freiwald, A.: Scleractinian cold-water corals in the Gulf of Cádiz - first clues about their spatial and temporal distribution, Deep-Sea Res. Pt. I, 56, 1873 1893, 2009.

Williams, A., Schlacher, T. A., Rowden, A. A., Althaus, F., Clark, M. R., Bowden, D. A., Stewart, R., Bax, N. J., Consalvey, M., and Kloser, R. J.: Seamount megabenthic assemblages fail to recover from trawling impacts, Mar. Ecol., 31, 183-199, 2010.

Wilson, R. R. and Kaufmann, R. S.: Seamount biota and biogeography, in: Seamounts, Islands, and Atolls, edited by: Keating, B. H., Fryer, P., Batiza, R., and Boehlert, G. W., American Geophysical Union, 355-378, 1987.

Wright, D. J., Lundblad, E. R., Larkin, E. M., Rinehart, R. W., Murphy, J., Cary-Kothera, L., and Draganov, K.: ArcGIS Benthic Terrain Modeler, Corvallis, Oregon, Oregon State University, Davey Jones Locker Seafloor Mapping/Marine GIS Laboratory and NOAA Coastal Services Center. Accessible online at: http://maps.csc.noaa.gov/digitalcoast/tools/btm, 2005.

Yesson, C., Clark, M. R., Taylor, M. L., and Rogers, A. D.: The global distribution of seamounts based on 30 arc seconds bathymetry data, Deep-Sea Res. Pt. I, 58, 442-453, 2011.

Zitellini, N., Gràcia, E., Matias, L., Terrinha, P., Abreu, M. A., DeAlteriis, G., Henriet, J. P., Dañobeitia, J. J., Masson, D. G., Mulder, T., Ramella, R., Somoza, L., and Diez, S.: The quest for the Africa-Eurasia plate boundary west of the Strait of Gibraltar, Earth Planet. Sci. Lett., 280, 13-50, 2009. 